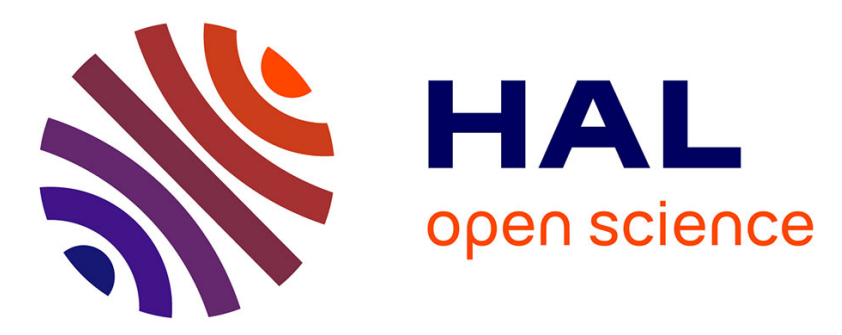

\title{
Review of literature on Ruthenium Behaviour in Nuclear Power Plant Severe Accidents
}

\author{
Charles Madic, Christian Mun, Laurent Cantrel
}

\section{To cite this version:}

Charles Madic, Christian Mun, Laurent Cantrel. Review of literature on Ruthenium Behaviour in Nuclear Power Plant Severe Accidents. Nuclear Technology, 2017, 156 (3), pp.332-346. 10.13182/NT156332 . irsn-00177621v2

\section{HAL Id: irsn-00177621 \\ https://hal-irsn.archives-ouvertes.fr/irsn-00177621v2}

Submitted on 12 May 2020

HAL is a multi-disciplinary open access archive for the deposit and dissemination of scientific research documents, whether they are published or not. The documents may come from teaching and research institutions in France or abroad, or from public or private research centers.
L'archive ouverte pluridisciplinaire HAL, est destinée au dépôt et à la diffusion de documents scientifiques de niveau recherche, publiés ou non, émanant des établissements d'enseignement et de recherche français ou étrangers, des laboratoires publics ou privés. 


\title{
REVIEW OF LITERATURE ON RUTHENIUM BEHAVIOR IN NUCLEAR POWER PLANT SEVERE ACCIDENTS
}

\author{
C. MUN* and L. CANTREL Institut de Radioprotection et de Sûreté Nucléaire \\ Direction de la Prévention des Accidents Majeurs, CEN Cadarache \\ Bât 702, F-13115 Saint Paul lez. Durance, France \\ C. MADIC Commissariat à l'Energie Atomique \\ Direction de l'Energie Nucléaire, Centre de Saclay, 91191 Gif-sur-Yvette Cedex, France
}

During a hypothetical severe accident in a pressurized water reactor $(P W R)$, fission products $(F P s)$ are released from the nuclear fuel and may reach the reactor containment building. Among the FPs, ruthenium is of particular interest due to its ability to form volatile oxide compounds in highly oxidizing conditions. In addition, ruthenium is a very hazardous compound because it is chemically toxic and also because of its radiotoxicity.

The topic of ruthenium is examined in terms of nuclear safety issues. A review of the literature regarding ruthenium oxides properties, gaseous and aqueous chemistry is compiled. The study focuses on ruthenium tetroxide $\left(\mathrm{RuO}_{4}\right)$, which is highly reactive and volatile and is the most likely gaseous chemical form under the conditions prevailing in the containment. The interactions between ruthenium oxides and containment surfaces, which could be most important in overall ruthenium behavior, are also discussed. Finally, an evaluation of the possible revolatilization phenomena of ruthenium adsorbed on PWR containment surfaces or dissolved in the sump under superoxidizing conditions (radiolysis) is also presented. In this case, ruthenium dioxide $\left(\mathrm{RuO}_{2}\right)$ must also be considered.

Knowledge of all these phenomena is required to accurately predict ruthenium behavior and to make a best-estimate assessment of the potential ruthenium source term.

\section{BACKGROUND}

A severe accident would happen in a nuclear reactor if loss of coolant due to an initiating event occurs together with partial or total failure of the safeguard systems, leading to irreversible core dewatering. After the nuclear fuel degradation, fission products released from fuel are transported in gas, vapor, or

*E-mail: christian.mun@irsn.fr

aerosol form through the reactor coolant system (RCS), partially condensed onto steel surfaces, and reach the containment. Some fission products, still in gas or aerosol form, may leave the containment via different leaks and will lead to radioactive contamination of the environment: This is called source term.

Among all types of severe accidents, some happen in a highly oxidizing atmosphere due to possible contact between degraded fuel and air. The different possible air ingress pathways have been studied, 1,2 and three main possibilities have been identified.

The first one corresponds to air ingress during refueling operations. During this process, the reactor vessel head is removed and the fuel is immersed in water. In the case of possible water loss, the refueling cavity could be emptied and fuel would come into direct contact with the air. ${ }^{1}$

The second possibility is air ingress following lower-head reactor pressure vessel melt-through due to molten nuclear fuel (called corium) interaction with steel. ${ }^{2}$ Indeed, subsequent to this phenomenon, a gas circulation is created between the reactor pit, lower-head vessel break, and the primary system.

The last possibility is air ingress directly through a break in the primary or secondary coolant system. ${ }^{1}$

Other scenarios leading to contact between fuel and air are possible, e.g., a spent-fuel storage pool water-draining accident or a fuel-handling accident.

This technical note reviews the literature regarding ruthenium oxides gaseous and aqueous chemistry in the containment during an oxidizing severe accident. This study focuses particularly on the ruthenium tetroxide chemistry.

\section{RUTHENIUM ISSUE}

\section{II.A. Does Ruthenium Represent a Real Issue for Nuclear Safety?}

The study of ruthenium by Institut de Radioprotection et de Sûreté Nucléaire as well as other organizations devoted to nuclear safety research in France and other countries is motivated by several factors. 


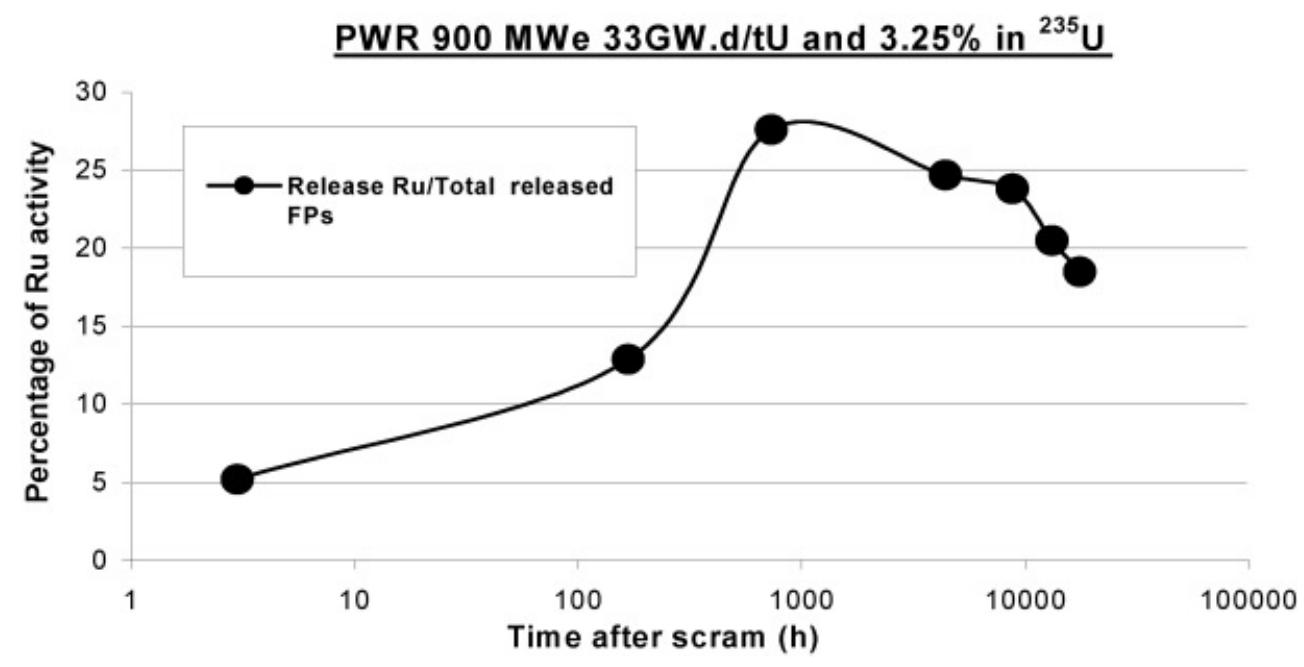

Fig. 1. Percentage of ruthenium activity compared to the total activity of all other fission products.

First, the quantity of ruthenium formed increases with fuel burnup. With identical burnup, it increases with fuel enrichment in ${ }^{235} \mathrm{U}$; moreover, it is greater in mixed-oxide fuel than in $\mathrm{UO}_{2}$ fuel. As a consequence, the amount of ruthenium formed during fuel life will continuously rise in the future, because utilities tend to optimize fuel performances.

Second, ruthenium is a high-specific-activity fission product. The graph in Fig. 1 shows the evolution, during the first $2 \mathrm{yr}$ after an emergency scram, of the important part of ruthenium activity with respect to the total activity of all the fission products released $\left({ }^{131} \mathrm{I},{ }^{133} \mathrm{Xe} \text {, etc. }\right)^{3,4}$; it has been assumed that $50 \%$ of the bundle inventory is released.

Finally, ruthenium has, in addition to its chemical toxicity, which was already known through toxicological studies, ${ }^{5-7}$ a high radiotoxicity, essentially through its isotopes ${ }^{106} \mathrm{Ru}$ $\left(T_{1 / 2}=369\right.$ days $)$ and ${ }^{103} \mathrm{Ru}\left(T_{1 / 2}=39.3\right.$ days $)$. It is therefore an important short- and middle-term radiocontaminant.

In radiological protection, four groups of radionuclides were defined, ${ }^{8}$ and ${ }^{106} \mathrm{Ru}$ was ranked in group 2 , high radiotoxicity, in the same way as ${ }^{131} \mathrm{I}$, and ${ }^{103} \mathrm{Ru}$ in group 3, moderate radiotoxicity, as ${ }^{137} \mathrm{Cs}$.

The danger of ruthenium particles is their specific activity and the high associated risk of irradiation and internal contamination (inhalation, ingestion). For example, an 8 - $\mu$ m-diam particle that has a $1500-\mathrm{Bq}$ activity [calculated for RBMK fuel (Chernobyl) with an average burnup] may induce $>1.6 \mathrm{mGy} /$ $\mathrm{cm}^{2} \cdot \mathrm{h}$ to skin (external irradiation). ${ }^{9}$

Under the action of oxidizing agents, which may be produced either from sump water radiolysis or from air radiolysis, ruthenium metal or dioxide could be oxidized up to + VIII oxidation state. Its volatile compounds (essentially $\mathrm{RuO}_{4}$ ) may be present in the containment in the case of a severe accident and could represent a high potential risk for nuclear safety.

\section{II.B. Ruthenium Release from Degraded Fuel and Transport in RCS}

Metal ruthenium is considered as a moderately volatile species; then the fraction emitted, from $\mathrm{UO}_{2}$ fuel heated to
$2573 \mathrm{~K}$, varies between 1 and 10\% (Ref. 10). Indeed, according to the Ellingham diagram, to obtain ruthenium oxides, it is necessary to have preliminarily oxidized most of the other elements, especially uranium, plutonium, and molybdenum. The presence of volatile ruthenium species is possible only if the fuel is subject to strong oxidation, such as the one resulting from air ingress in the reactor pressure vessel. Affinity for oxygen is in decreasing order: $\mathrm{Zr}>\mathrm{UO}_{2}>\mathrm{Ru}$. So oxygen availability for ruthenium depends strongly on the $\mathrm{UO}_{2}$ matrix oxidation state. ${ }^{1}$ As indicated by Hunt et al., ${ }^{11}$ some elements can become oxidized (ruthenium extreme case) only if $\mathrm{UO}_{2}$ has previously been oxidized in $\mathrm{UO}_{2+x}$. Oxygen potential is of prime importance for the ruthenium release rate.

Ruthenium release from the fuel matrix (or simulant) under air atmosphere has been highlighted by various experiments.

Atomic Energy of Canada Limited carried out some tests that consisted of heating pieces of irradiated fuel pellets under different atmospheres. The fuel burnup of the test called H02 was $10 \mathrm{GWd} / \mathrm{t} \mathrm{U}$. This test was performed in an $\mathrm{Ar} / \mathrm{H}_{2}$ atmosphere and next in air. The maximum temperature reached was $2163 \mathrm{~K}$. Figure 2 shows that as soon as an oxidizing atmosphere is present (transition from $\mathrm{Ar} / \mathrm{H}_{2}$ mixture to air atmosphere), ruthenium release increases drastically to reach a value close to that of ${ }^{133} \mathrm{Xe}$, which is a very volatile compound released at nearly $100 \%$. It is worth noticing the presence of an induction time $(\sim 5000 \mathrm{~s})$ assumed to correspond to the time necessary for oxidation of the $\mathrm{UO}_{2}$ matrix by air; the next ruthenium release is extremely quick. ${ }^{12}$

In the framework of the PHEBUS-RUSET program, in 2002 the Hungarian research organization AEKI studied the ruthenium release at high temperature in an oxidizing environment. These tests confirmed the presence of a gaseous type of ruthenium. ${ }^{13}$

Once released out of the fuel matrix, ruthenium can be transported through the RCS under various physicochemical forms: ruthenium trioxide $\left[\mathrm{RuO}_{3}(\mathrm{~g})\right]$, ruthenium tetroxide $\left[\mathrm{RuO}_{4}(\mathrm{~g})\right], \mathrm{RuO}_{2}$ aerosol (ruthenium dioxide), and ruthenium mixed aerosols $\left(\mathrm{Cs}_{2} \mathrm{RuO}_{4} \ldots\right)$ before reaching the containment via the RCS break. 


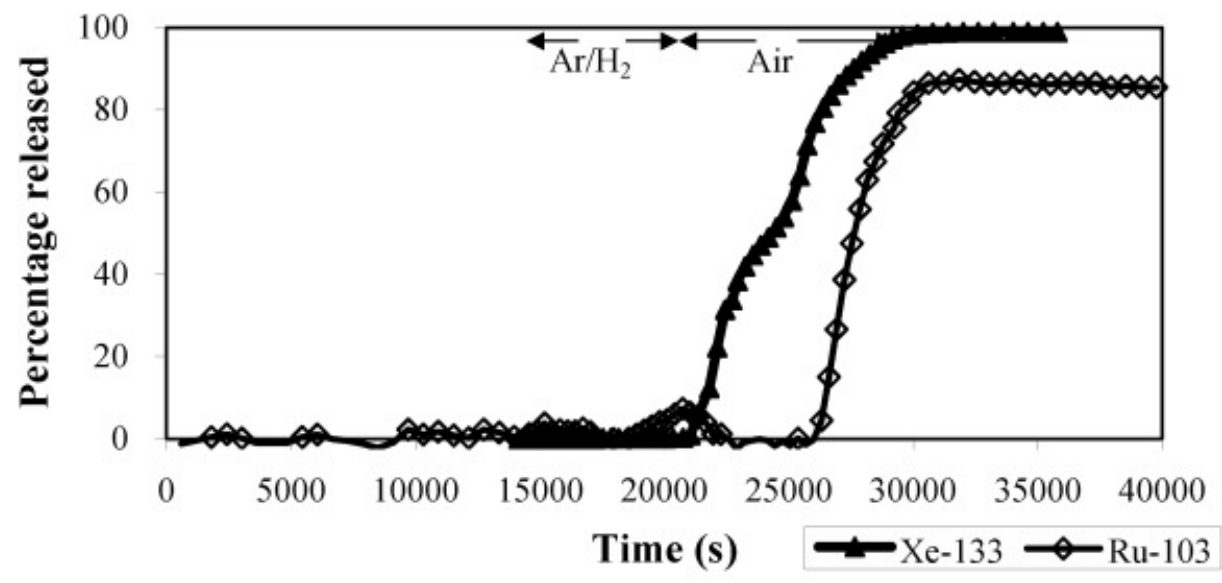

Xenon and Ruthenium release percentages as functions of time for $\mathrm{HCE} 3$ test $\mathrm{H} 02$ (sheathed Darlington fuel, air, $1890^{\circ} \mathrm{C}$ ).

Fig. 2. Variation of ruthenium and xenon releases according to the nature of gas flow. ${ }^{12}$

The British technology company AEA-Technology and VTT Processes (Finland) have studied ruthenium transport. It has been observed that the $\mathrm{RuO}_{4}$ partial pressure measured is far higher than the predicted thermodynamic equilibrium calculation, so ruthenium tetroxide decomposition may have been limited. ${ }^{14,15}$ Similar results were obtained in other experiments. ${ }^{16}$

Interesting information can also be drawn from the Chernobyl accident even if this accident is not strictly a pressurized water reactor (PWR) severe accident; nevertheless, a strong ruthenium release occurred. Indeed, total releases of ${ }^{103} \mathrm{Ru}$ were higher than those of ${ }^{137} \mathrm{Cs}, 9.3 \times 10^{16}$ versus $4.7 \times 10^{16}$ $\mathrm{Bq}$ (Ref. 17), corresponding to $\sim 2.9 \%$ of the ruthenium initial inventory, ${ }^{18}$ so it confirms the possibility that ruthenium can be released outside the fuel matrix.

Many radioactive particles emitted contain ruthenium, essentially in metal form. ${ }^{17}$ Various authors have tried to explain the origin of this metal form, but assumptions vary from one author to another. Nevertheless, Broda et al. ${ }^{19}$ have formulated a pertinent hypothesis: They postulated that some radioactive compounds, emitted in gas form, precipitated and condensed when they reached the airborne plume. Ruthenium and molybdenum volatile oxides, formed due to heating from graphite combustion, reduced or decomposed at high temperature, are probably the main compounds of such precipitates. This scenario has been subsequently suggested as the origin of the very high purity of radioactive ruthenium and of the fact that many particles have been found incorporated in large fragments of nonradioactive material. In addition, the formation of volatile compounds is also confirmed, because the condensed ruthenium particles showed a constant ${ }^{103} \mathrm{Ru} /{ }^{106} \mathrm{Ru}$ isotopic ratio.

This is only possible if they come from an initial gaseous release form because this ratio depends on burnup, so variable according to the ruthenium location in the fuel matrix.

In the release of solid particles from fuel, this ratio could not be identical, it would change according to the fragments analyzed. ${ }^{20}$
All these experimental observations indicate that ruthenium can be released from fuel in large quantities according to conditions and next transported through the RCS. But then, how do emitted ruthenium compounds behave in the containment?

\section{II.C. Ruthenium Behavior in the Reactor Containment}

Ruthenium behavior is directly linked to the nature of the ruthenium compound. The $\mathrm{RuO}_{3}(\mathrm{~g})$ is unlikely to reach the containment because it is thermodynamically unstable in the temperature range of the containment severe-accident conditions. ${ }^{21,22}$ In the gas phase, mixed aerosols are not the major risk from a source-term point of view, because after aerosol settling in the aqueous phase (sump), ruthenates will be formed. The two essential species are $\mathrm{RuO}_{4}$, the most stable gaseous form in containment conditions, and the little soluble aerosol $\mathrm{RuO}_{2}$, which can have an impact in terms of potential revolatilization under $\mathrm{RuO}_{4}$ form.

In the aqueous phase, ionic compounds of ruthenium, essentially $\mathrm{RuO}_{4}^{-} / \mathrm{RuO}_{4}^{2-}$, have to be taken into account because they can be involved in reactions leading to the formation of either gaseous $\mathrm{RuO}_{4}$ or $\mathrm{RuO}_{2}$.

The potential reactivity of ruthenium onto surfaces is important. Therefore, the important surfaces present inside the PWRs' containment have to be considered in terms of reactivity; these surfaces are made of painted steel and stainless steel surfaces (Types 316L and 304L) (Ref. 23). Ruthenium tetroxide seems to have a certain affinity for iron oxides ${ }^{22,24}$ and for organic compounds. ${ }^{25,26}$ Reactions involving $\mathrm{RuO}_{4}$ with the internal surfaces of the containment can be expected to occur, especially as the developed total surface is very large-several thousands of square meters.

During a severe accident, there is a high dose rate in the containment in the gaseous and aqueous phases resulting from the large amount of fission products present in the containment. Radiolytic reactions occur in the atmosphere and the sump leading to the formation of oxidants that might oxidize ruthenium up to a + VIII oxidation state. 


\section{GENERAL PROPERTIES CONCERNING RUTHENIUM OXIDES}

Although it is an iron homologue, ruthenium has neither the same reactivity nor the same chemistry. Ruthenium chemistry is extremely complex; many compounds are knowninorganic as well as organic forms. Its external electronic structure is $4 \mathrm{~d}^{7} 5 \mathrm{~s}^{1}$, which gives it nine stable oxidation states lying between 0 and +VIII, and even a - II oxidation state, $\left[\mathrm{Ru}(\mathrm{CO})_{4}^{2-}\right]$ (Ref. 25). Our paper is limited to compounds that could be involved in nuclear safety issues.

With alkali metals and alkali earth metals present in large quantity as fission products, ruthenium can form mixed compounds, such as $\mathrm{Cs}_{2} \mathrm{RuO}_{4}, \mathrm{SrRuO}_{4}, \mathrm{BaRuO}_{3}$, etc.

Ruthenium halides can also be quoted: $\mathrm{RuF}_{6}$ to $\mathrm{RuF}_{3}$, $\mathrm{RuCl}_{3}, \mathrm{RuCl}_{2}, \mathrm{RuI}_{3}, \mathrm{RuI}_{2}, \ldots$ (Ref. 27). The last two compounds are of particular interest, because iodine is a very hazardous fission product. ${ }^{28}$ In aqueous phase, oxidation states + VI, + VII, and + VIII give essentially tetrahedric oxocomplex ruthenate ions $\left(\mathrm{RuO}_{4}^{2-}\right)$ and perruthenate ions $\left(\mathrm{RuO}_{4}^{-}\right)$, as well as ruthenium tetroxide and its hydrolyzed form, $\mathrm{H}_{2} \mathrm{RuO}_{5}$.

The possible existence of ruthenium hydroxides and ruthenium oxyhydroxides is mentioned in the literature even if the data are scarce.

Besides metal ruthenium, ruthenium aerosols (type $\mathrm{Cs}_{2} \mathrm{RuO}_{4}$ ), and possibly ruthenium hydroxides, ruthenium oxides are the main compounds supposed to be formed during a severe accident. The four main ruthenium oxides are $\mathrm{RuO}$, $\mathrm{RuO}_{2}, \mathrm{RuO}_{3}$, and $\mathrm{RuO}_{4}$ (Ref. 29).

Table I lists all the ruthenium compounds that may be concerned in this topic; they are classified according to their oxidation states. Letters (g), (aq), and (c) refer, respectively, to gaseous, aqueous, and condensed phases.

The main characteristics of ruthenium oxide compounds are the following:

1. RuO: This oxide is only gaseous. According to Shäfer et al., when the temperature is $>1273 \mathrm{~K}$, the three oxides $\mathrm{RuO}_{4}$, $\mathrm{RuO}_{3}$, and $\mathrm{RuO}_{2}$ are decomposed into $\mathrm{RuO}$ (Ref. 30). How- ever, various authors, such as $\operatorname{Rard}^{31}$ and Bell ${ }^{21}$ have doubts concerning its existence. After experimental works, Eichler et al. ${ }^{29}$ claim that $\mathrm{RuO}$ monoxide only exists when temperatures are $>1900 \mathrm{~K}$. Enthalpy of formation has been established by Norman et al. ${ }^{32}$ at $1900 \mathrm{~K}$.

2. $\mathrm{RuO}_{2}$ : Ruthenium dioxide is the most stable ruthenium oxide. It appears under brown-black powder with a tetragonal rutile structure, type $\mathrm{TiO}_{2}$. One means of production is to roast $\mathrm{Ru}_{\text {metal }}$ in an oxygen stream in a very high temperature muffle furnace $^{25}$; another is to dehydrate $\mathrm{Ru}(\mathrm{OH})_{3}$ hydroxide at $723 \mathrm{~K}$ (Ref. 33). By heating $\mathrm{RuO}_{2}$ under an oxygen flow, volatilization takes place, indicating the formation of higher oxidationstate oxides. These oxides, which are thermodynamically unstable, decompose on cooling to form anhydrous $\mathrm{RuO}_{2}$ blue crystals. This phenomenon has been experimentally confirmed by Rard. ${ }^{31}$ In anhydrous form, dioxide is insoluble, but a hydrated form exists $\left(\mathrm{RuO}_{2}, x \mathrm{H}_{2} \mathrm{O}\right.$ with $\left.2<x<3\right)$, so its dissolution becomes possible ${ }^{33}$ even if this is quite difficult. $\mathrm{RuO}_{2}$ is also assumed to exist in gaseous form but solely at very high temperatures, $>2000 \mathrm{~K}$ (Ref. 34), as in the reactor core in severe-accident conditions.

3. $\mathrm{RuO}_{3}$ : Very little information is available in the literature concerning this oxide. Its existence in gas form was questioned for a long time, but Schäfer et al. ${ }^{30}$ and Bell and Tagami ${ }^{21}$ in 1963 proved its existence. According to these authors, the partial pressures of ruthenium trioxide and ruthenium tetroxide are equal in a $\left(\mathrm{RuO}_{2}+\mathrm{O}_{2}\right)$ environment at $1 \mathrm{~atm}$ and at $1327 \mathrm{~K}$. $\mathrm{RuO}_{3}$ predominates in the gaseous phase above this temperature up to $2000 \mathrm{~K}$, and $\mathrm{RuO}_{4}$, below this temperature $(1327 \mathrm{~K})$. Eichler et al. ${ }^{29}$ indicate that ruthenium trioxide in a gaseous phase can condense in dioxide form. Moreover, $\mathrm{RuO}_{3}(\mathrm{~g})$ could also be transformed in solid $\mathrm{RuO}_{3}$ form ${ }^{35}$ even if this hypothesis is not accepted by all the scientific community.

4. $\mathrm{RuO}_{4}$ : Ruthenium tetroxide can exist in a gaseous state or in a condensed state. The properties of this compound are extensively detailed later. An important characteristic is that

TABLE I

Possible Ruthenium Oxidation States Discussed in This Paper

\begin{tabular}{|c|c|c|c|}
\hline $\begin{array}{l}\text { Oxidation } \\
\text { State }\end{array}$ & Type of Compound & Name & Physical State \\
\hline+8 & $\mathrm{RuO}_{4}$ (associated with $\mathrm{H}_{2} \mathrm{RuO}_{5} / \mathrm{HRuO}_{5}^{-}$) & Ruthenium tetroxide & $(\mathrm{c}),(\mathrm{aq}),(\mathrm{g})$ \\
\hline+7 & $\mathrm{RuO}_{4}^{-}$ & Perruthenate ion & $(\mathrm{aq})$ \\
\hline+6 & $\begin{array}{l}\mathrm{RuO}_{4}^{2-} \\
\mathrm{RuO}_{3}\end{array}$ & $\begin{array}{l}\text { Ruthenate ion } \\
\text { Ruthenium trioxide }\end{array}$ & $\begin{array}{l}(\mathrm{aq}) \\
(\mathrm{g})\end{array}$ \\
\hline+5 & $\mathrm{Ru}_{2} \mathrm{O}_{5}, 2 \mathrm{H}_{2} \mathrm{O}$ & Hydrated pentavalent ruthenium oxide & (c) \\
\hline+4 & $\begin{array}{l}\mathrm{RuO}_{2} \\
\mathrm{RuO}_{2}, 2 \mathrm{H}_{2} \mathrm{O} \\
\mathrm{Ru}(\mathrm{OH})_{2}^{2+} / \mathrm{Ru}_{4}(\mathrm{OH})_{12}^{4+} \\
\mathrm{Ru}(\mathrm{OH})_{4}\end{array}$ & $\begin{array}{l}\text { Ruthenium dioxide } \\
\text { Hydrated ruthenium dioxide } \\
\text { Ruthenium monomer/tetramer } \\
\text { Ruthenium hydroxide }\end{array}$ & $\begin{array}{l}(\mathrm{c}) \\
(\mathrm{c}) \text { and }(\mathrm{aq}) \\
(\mathrm{aq}) \\
(\mathrm{aq})\end{array}$ \\
\hline+3 & $\mathrm{Ru}^{3+} / \mathrm{Ru}(\mathrm{OH})_{3}$ & Trivalent cation and its hydroxide & $(\mathrm{aq})$ \\
\hline+2 & $\mathrm{Ru}^{2+}$ & Divalent cation & $(\mathrm{aq})$ \\
\hline 0 & Ruthenium & Metal ruthenium & (c) \\
\hline
\end{tabular}


this oxide is very volatile with very toxic vapors. To illustrate this point, the liquid-vapor equilibrium constant of ruthenium tetroxide has been calculated with GEMINI 1 (Ref. 36) and the thermodynamic databank associated $\mathrm{COACH}$ :

$$
\mathrm{RuO}_{4}(\mathrm{aq}) \Leftrightarrow \mathrm{RuO}_{4}(\mathrm{~g}) \quad \mathrm{K}=8.8 \times 10^{-2} \text { at } 360 \mathrm{~K} .
$$

The constant of this reaction represents the $\mathrm{RuO}_{4}$ vapor pressure in the standard reference state.

\section{RUTHENIUM OXIDE CHEMISTRY IN SEVERE- ACCIDENT CONDITIONS}

\section{IV.A. Ruthenium Reactivity in Gas Phase}

From a nuclear safety point of view, ruthenium compounds can be split into two categories, the gaseous forms and the aerosol forms, amounts of which are very much predominant. Possible gaseous forms can only be $\mathrm{RuO}_{3}$ and $\mathrm{RuO}_{4}$. However, the maximal temperature in the containment in the case of a severe accident will very likely remain below $413 \mathrm{~K}$, a value not compatible with the thermodynamic stability of trioxide, ${ }^{21,22}$ as already mentioned.

Figure 3, obtained by means of the thermodynamic code COACH-GEMINI 1 (Ref. 36), indicates clearly that $\mathrm{RuO}_{3}$ decomposes at $\sim 1500 \mathrm{~K}$ to form $\mathrm{RuO}_{2}$ and $\mathrm{RuO}_{4}$.

Even if thermodynamic equilibrium calculations also show $\mathrm{RuO}_{4}(\mathrm{~g})$ instability at low temperature and all the more in the temperature range of the containment ( 313 to $413 \mathrm{~K}$ ), several arguments favor a more complete study of the reactivity associated with this species.

First, recent experimental data ${ }^{13,14}$ tend to prove that $\mathrm{RuO}_{4}$ would be formed in the RCS in a nonnegligible amount. Second, $\mathrm{RuO}_{4}$ has a very high saturation vapor pressure, so its volatility makes it hazardous for the population. Third, in the reactor containment conditions (oxidizing medium), this high oxidation state $(+$ VIII) could be stabilized.
Concerning aerosols, there are mixed ruthenium aerosols and ruthenium dioxide $\mathrm{RuO}_{2}(\mathrm{~s})$. Mixed aerosols are water soluble, and ruthenium dioxide, on first analysis, does not represent a major danger in this form, except in the case of early containment failure, but it can be a possible source of $\mathrm{RuO}_{4}(\mathrm{~g})$ formation by oxidation of aerosol deposits on the walls. To sum up, to be able to make an accurate estimation of the ruthenium source term, a better understanding of tetroxide and dioxide behavior is needed.

\section{IV.A.1. Ruthenium Tetroxide}

For several authors, ${ }^{24,37}$ ruthenium tetroxide appears in two forms in solid state. The first condensed state is brownish globules, which are little soluble in water and seem to constitute a crystalline state. They are produced by solidification of liquid tetroxide below $300 \mathrm{~K}$. The second state corresponds to very unstable yellow needles, which are obtained by condensation of tetroxide in the vapor state. These needles melt at $\sim 298 \mathrm{~K}$. This form is more soluble in water and produces a golden yellow solution; its solubility in water is estimated at $17.1 \mathrm{~g} / \ell$ at $273 \mathrm{~K}$ and $20.3 \mathrm{~g} / \ell$ at $293 \mathrm{~K}$ (Ref. 26). It is also very soluble in tetrachloromethane and produces an orange red solution. Its sublimation can be observed at $280 \mathrm{~K}$ with a pressure of $\sim 4$ mbar (Ref. 24). This crystalline form can be obtained with sublimation and next condensation of the brownish form.

However, a study by Nikol'skii ${ }^{38}$ focused on determining the melting point, vapor pressure, and solubility in water refutes this hypothesis of ruthenium tetroxide polymorphism.

Tetroxide vapors are yellow and toxic and smell strongly like ozone. They are reactive, particularly with organic materials and reducing agents. Sensitivity to photolysis has also been demonstrated. ${ }^{35}$ Indeed, in a dark place in dry atmosphere and in a sealed tube, ruthenium tetroxide can be stored for several years. On the other hand, with light and humidity, its decomposition happens quickly.

The duration was not indicated. $\mathrm{RuO}_{4}$ is also supposed to decompose in an explosive way into $\mathrm{RuO}_{2}$ when temperatures

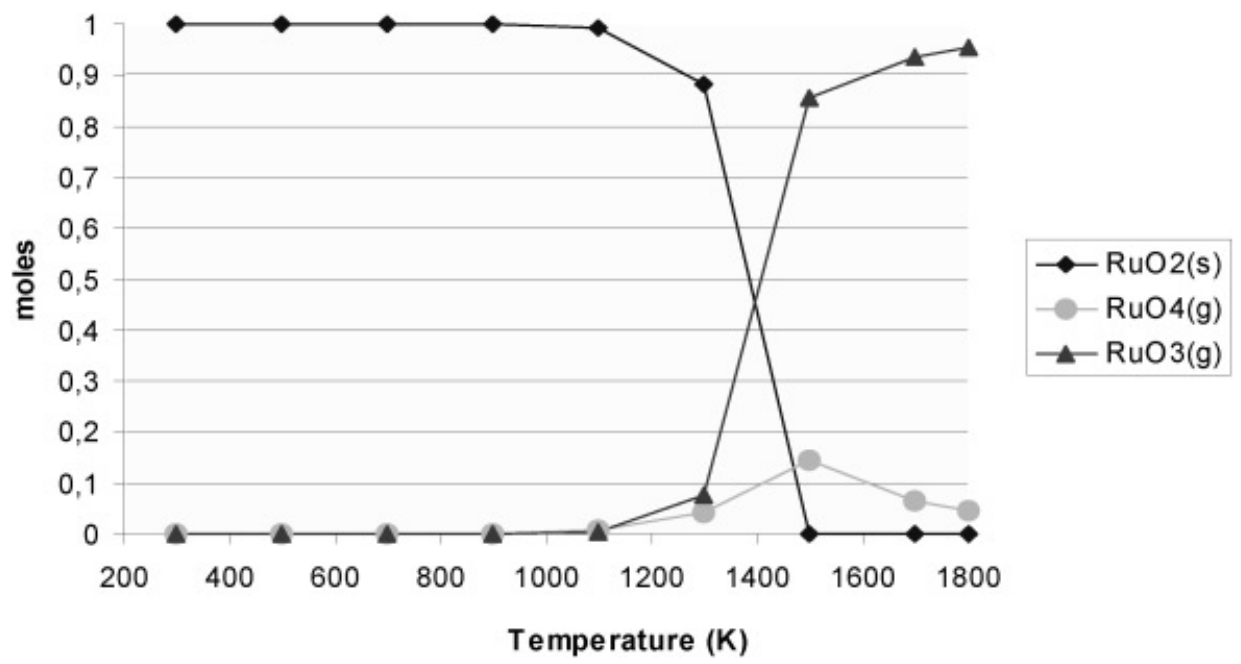

Fig. 3. Thermodynamic stability of $\mathrm{RuO}_{4}(\mathrm{~g}), \mathrm{RuO}_{3}(\mathrm{~g})$, and $\mathrm{RuO}_{2}(\mathrm{~s})$ as a function of temperature for, respectively, 1 mol of ruthenium, $200 \mathrm{~mol}$ of $\mathrm{H}_{2} \mathrm{O}$, and $200 \mathrm{~mol}$ of $\mathrm{O}_{2}(15 \% M)$. 
are near $381 \mathrm{~K}$ (Ref. 39). This last point is not mentioned in any other paper; nevertheless, it is worth noticing that only these authors have manipulated $\sim 100 \mathrm{~g}$ of tetroxide, which represents a huge amount—never handled again.

IV.A.1.a. Thermal Stability of $\mathrm{RuO}_{4}(g) . \mathrm{RuO}_{2}$ stability and $\mathrm{RuO}_{4}$ volatility can be easily explained with covalent bonds. Binding energy between tetroxide atoms is low because they are perfectly saturated, and the structure is symmetrical, so this compound can be easily melted, sublimated, and volatilized.

Few experimental studies on ruthenium tetroxide stability in gaseous phase have been performed. Ruthenium tetroxide decomposition mechanisms and the associated kinetics are still unknown. According to Leudet, ${ }^{40}$ tetroxide decomposition at low temperatures takes place according to the following reaction:

$$
\mathrm{RuO}_{4}(\mathrm{~g}) \Leftrightarrow \mathrm{RuO}_{2}(\mathrm{~s})+\mathrm{O}_{2} \quad \mathrm{~K}=\mathrm{P}_{\mathrm{O}_{2}} / \mathrm{P}_{\mathrm{RuO}_{4}}
$$
relation:

The equilibrium constant is provided by the following

$$
\ln \mathrm{K}=\frac{14880}{T}-11.53+1.135 \ln T \quad(T \text { in } \mathrm{K})
$$

The $\mathrm{RuO}_{4}(\mathrm{~g})$ stability rises with temperature. The equilibrium constant calculated $\left(7 \times 10^{19}\right.$ at $293 \mathrm{~K}$ and $2 \times 10^{15}$ at $373 \mathrm{~K}$ ) indicates an almost complete decomposition if equilibrium is reached.

Ortner ${ }^{41}$ introduced gaseous tetroxide in a sealed tube (Carius tube) maintained at a constant temperature for some time and then rapidly cooled to stop the reaction, but the precise boundary experimental conditions were not provided.

They noticed that in the presence of wet air, decomposition happens only after an induction time, the duration of which depends on steam concentration and temperature. But, after adding a drying agent, the induction time has been shortened. No hypothesis was formulated.

The decomposition seems to be initiated by ruthenium deposition on glass walls; this would indicate an autocatalytic reaction, all the more that in introducing $\mathrm{RuO}_{2}$ into the tube, induction time was also reduced. The decomposition kinetic was studied between 383 and $413 \mathrm{~K}$ with an $\mathrm{RuO}_{4}$ initial pressure of $\sim 0.3 \mathrm{~atm}$ in the presence of 25 to $150 \mathrm{mg}$ of $\mathrm{RuO}_{2}$. The determined kinetic rate law is of first order with respect to $\mathrm{RuO}_{4}$. An Arrhenius law expressed the rate constant:

$$
k\left(\min ^{-1}\right)=7.12 \times 10^{14} \exp \left(-128 \times 10^{3} /(\text { room temperature })\right)
$$

$(T$ in $\mathrm{K})$.

Corresponding reaction half-lives calculated at different temperatures are reported in Table II.

The kinetics of the $\mathrm{RuO}_{4}$ decomposition is very slow at room temperature, which may justify the existence of $\mathrm{RuO}_{4}(\mathrm{~g})$ even if it is not thermodynamically stable. The temperature range $(\Delta T=30 \mathrm{~K})$, where the kinetic data were determined, is limited, and above $373 \mathrm{~K}$, extrapolation is uncertain. Moreover, the possible explosive decomposition of tetroxide at temperatures near $381 \mathrm{~K}$ noticed by Sainte Claire Deville and Debray $^{39}$ is not consistent with this study even if the possible explanation is that the amount of the tetroxide involved in these tests was weaker. The influence of the presence of metal ruthenium in powder form on the decomposition rate has also
TABLE II

Ruthenium Tetroxide Decomposition Kinetic Constant Between 293 and $423 \mathrm{~K}$ (Ref. 41)

\begin{tabular}{|c|c|c|}
\hline $\begin{array}{c}\text { Temperature } \\
(\mathrm{K})\end{array}$ & $\begin{array}{c}k \\
\left(\mathrm{~min}^{-1}\right)\end{array}$ & $\begin{array}{c}\text { Calculated Half-Life } \\
(\mathrm{h})\end{array}$ \\
\hline 293 & $1.3 \times 10^{-8}$ & $8.9 \times 10^{5}$ \\
323 & $1.6 \times 10^{-6}$ & 7220 \\
373 & $9.6 \times 10^{-4}$ & 12 \\
423 & $1.2 \times 10^{-1}$ & $9.6 \times 10^{-2}$ \\
\hline
\end{tabular}

been studied. The results obtained for different concentrations of tetroxide indicate that $54 \%$ of $\mathrm{RuO}_{4}$ is decomposed after $3 \mathrm{~h}$ at $383 \mathrm{~K}$, and after $2 \mathrm{~h}$ at $413 \mathrm{~K}$, it is $100 \%$. Nevertheless, the lack of information about the precise conditions of experimentation limits the interest of these results.

At the end of the 19th century, Debray and Joly ${ }^{42}$ had already pointed out the impact of water steam on ruthenium tetroxide stability. Indeed, $\mathrm{RuO}_{4}$ can react with water steam to form a black coating of lower oxide. This black amorphous precipitate, dried in an oven at $383 \mathrm{~K}$, consists of $\mathrm{Ru}_{2} \mathrm{O}_{5}, 2 \mathrm{H}_{2} \mathrm{O}$, and even after drying, it remains partially hydrated. Tetroxide decomposition, which is slow in the dark, is accelerated with sunlight, especially with ultraviolet rays. According to Wöhler et al., ${ }^{43}$ dioxide hydrates would be formed.

Ortins de Bettencourt and Jouan ${ }^{24}$ have also investigated $\mathrm{RuO}_{4}$ decomposition kinetics. Even though they had great experimental difficulties, particularly in tetroxide generation and its transfer into the reactor vessel, they confirmed that the reaction is of first order.

More recently, Zimmerman et al. ${ }^{35}$ have again shown interest in $\mathrm{RuO}_{4}$ decomposition and the resulting products. Their study is based on irradiation of $\mathrm{RuO}_{4}(\mathrm{~g})$ by a mercury arc lamp or by a photolytic flash. Photolytic decomposition was observed in measuring the absorbance decrease of $\mathrm{RuO}_{4}$.

IV.A.1.b. $\mathrm{RuO}_{4}(\mathrm{~g})$ Reactivity Under Radiation. The formation of air radiolysis compounds has been extensively studied. ${ }^{44-46}$ Willis and Boyd ${ }^{47}$ published all the radiolytic yield values ( $G$ values) of primary compounds coming from air radiolysis, as well as the reactions between these different species. The set of thermal and radiolytic reactions can be solved by the Facsimile software ${ }^{48}$ in order to predict the gas mixture composition as a function of boundary conditions. By way of illustration, the main compounds generated by radiolysis are shown in Fig. 4 for prototypical conditions $(10 \mathrm{kGy} / \mathrm{h}$ dose rate, $373 \mathrm{~K}$, steam mass fraction $=30 \%$, and no potential sorption of radiolysis compounds on surfaces).

The main radiolytic compounds present in the containment in the case of a severe accident are $\mathrm{NO}_{2}, \mathrm{~N}_{2} \mathrm{O}$, and $\mathrm{O}_{3}$, which are oxidants.

The ruthenium tetroxide concentration in containment atmosphere is quite difficult to evaluate in a severe accident; it will nevertheless be extremely low with respect to atmospheric compounds. It is then legitimate to assume that most of the energy released by ionizing radiations is distributed between $\mathrm{N}_{2}, \mathrm{O}_{2}$, and $\mathrm{H}_{2} \mathrm{O}$ molecules, and the influence of radiation on ruthenium species will be due to chemical reactions with air radiolysis compounds rather than to direct radiations. The 


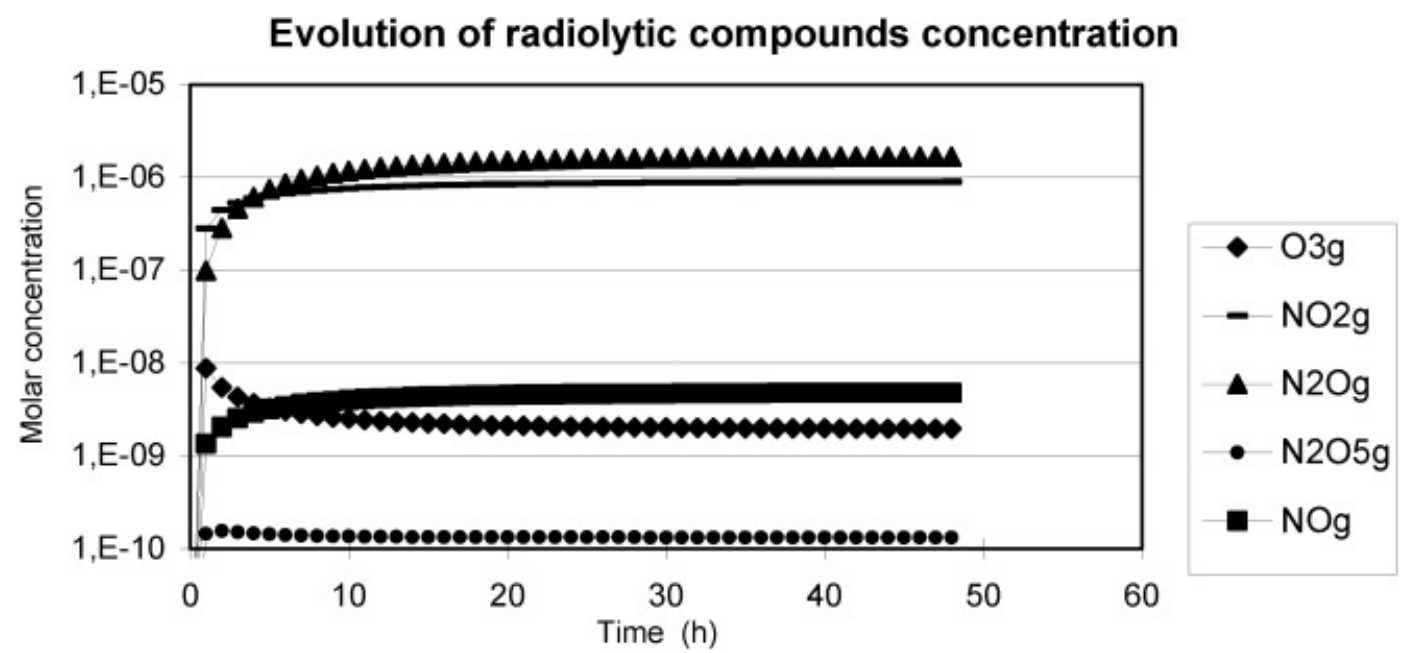

Fig. 4. Air radiolysis compounds concentration profiles as a function of time ( $\mathrm{DR}=10 \mathrm{kG} / \mathrm{h}$ at $373 \mathrm{~K}$, steam mass fraction $=30 \%)$.

$\mathrm{RuO}_{4}(\mathrm{~g})$ stability under radiolysis is legitimately questionable. The few experimental tests from literature are summarized in this paper.

Igarashi et al. ${ }^{49}$ have studied $\mathrm{NO}_{x}$ action on $\mathrm{RuO}_{4}(\mathrm{~g})$ stability. The addition of $\mathrm{NO}$ and $\mathrm{NO}_{2}$ facilitates ruthenium absorption in water. This effect is even stronger in the case of monoxide. Addition of $\mathrm{NO}_{2}$ with an $\mathrm{NO}_{2} / \mathrm{RuO}_{4}$ molar ratio of $\sim 189$ reduces the proportion of tetroxide in the gas phase by a factor of 168 , and the addition of NO with a 22 ratio, reduces it by 1180 .

This phenomenon could be due to tetroxide transformation into a nitrosylruthenium complex, which is less volatile and more soluble in water.

In 1955 , Fletcher et al. ${ }^{50}$ demonstrated the formation of a species of binuclear ruthenium. This species is obtained via the reaction

$$
2 \mathrm{RuO}_{4}+8 \mathrm{NO} \rightarrow \mathrm{Ru}_{2} \mathrm{~N}_{6} \mathrm{O}_{15}+\mathrm{N}_{2} \mathrm{O} .
$$

In the presence of water, the final compound is not only in $\mathrm{Ru}_{2} \mathrm{~N}_{6} \mathrm{O}_{15}$ form; aquo-nitrato- $\mathrm{RuNO}^{3+}$ forms are also generated. $^{51}$

\section{IV.A.2. Thermal and Radiolytic Reactivity of Ruthenium Dioxide}

If $\mathrm{RuO}_{2}$ (c) reactivity with air is reasonably limited because of its thermodynamic stability, a possible release of $\mathrm{RuO}_{4}(\mathrm{~g})$ at $600 \mathrm{~K}$ has been shown experimentally ${ }^{13}$ coming from the $\mathrm{RuO}_{2}$ (c) deposit; the $\mathrm{RuO}_{4}$ partial pressure measured is $\sim 10^{-6}$ bar. Maas and Longo ${ }^{52}$ also suspected the possibility of reoxidizing ruthenium dioxide with air at low temperatures.

From a theoretical point of view, the equilibrium constant calculated ${ }^{36}$ for the reaction $\mathrm{RuO}_{2}(\mathrm{~s})+\mathrm{O}_{2}(\mathrm{~g}) \leftrightarrow \mathrm{RuO}_{4}(\mathrm{~g})$ is equal to $5 \times 10^{-17}$ at $373 \mathrm{~K}$. For an oxygen partial pressure of $\sim 0.2$ bar, the resulting tetroxide concentration is $\sim 3 \times 10^{-19}$ $\mathrm{mol} / \ell$. This reaction cannot form tetroxide in great proportion. The $\mathrm{RuO}_{2}$ reactivity seems to be limited with oxygen, but for radiolysis products it is no longer the case.
Reactivity with ozone, $\mathrm{RuO}_{2}(\mathrm{~s})+\frac{2}{3} \mathrm{O}_{3}(\mathrm{~g}) \leftrightarrow \mathrm{RuO}_{4}(\mathrm{~g})$, is much higher, indeed $k=0.2$ at $373 \mathrm{~K}$. For prototypical ozone concentration, estimated at $\sim 10^{-8} \mathrm{~mol} / \ell$ or $3 \times 10^{-7}$ bar, the tetroxide partial pressure obtained is $\sim 2 \times 10^{-7}$ bar, or $6 \times$ $10^{-9} \mathrm{~mol} / \ell$ in terms of concentration.

Reactivity with nitrous oxide is also enhanced, as indicated by the following reaction:

$$
\begin{aligned}
\mathrm{RuO}_{2}(\mathrm{~s})+2 \mathrm{~N}_{2} \mathrm{O}(\mathrm{g}) \leftrightarrow \mathrm{RuO}_{4}(\mathrm{~g})+2 \mathrm{~N}_{2}(\mathrm{~g}) \\
\\
k=2.6 \times 10^{14} \text { at } 373 \mathrm{~K} .
\end{aligned}
$$

According to the air radiolysis model, for an $\mathrm{N}_{2} \mathrm{O}$ concentration of $\sim 10^{-6} \mathrm{~mol} / \ell$, corresponding to $3 \times 10^{-5} \mathrm{bar}$, the consumption of all $\mathrm{N}_{2} \mathrm{O}(\mathrm{g})$ will lead to the production of $\mathrm{RuO}_{4}$ with a $1.5 \times 10^{-5}$ bar partial pressure once equilibrium has been reached.

Another reaction between ruthenium dioxide and nitrogen dioxide is also possible by the following reaction:

$$
\begin{array}{r}
\mathrm{RuO}_{2}(\mathrm{~s})+2 \mathrm{NO}_{2}(\mathrm{~g}) \leftrightarrow \mathrm{RuO}_{4}(\mathrm{~g})+\mathrm{N}_{2}(\mathrm{~g})+\mathrm{O}_{2}(\mathrm{~g}) \\
k=0.2 \text { at } 373 \mathrm{~K} .
\end{array}
$$

If the $\mathrm{NO}_{2}$ concentration is identical to that of $\mathrm{N}_{2} \mathrm{O}$, equilibrium is not moved much to $\mathrm{RuO}_{4}(\mathrm{~g})$ formation. For a $\mathrm{NO}_{2}$ partial pressure equal to $10^{-6} \mathrm{~mol} / \ell, \mathrm{P}_{\mathrm{RuO} 4}$ should not be $>10^{-10}$ bar when equilibrium is reached. This reaction does not constitute a potential source of gaseous tetroxide formation.

Even if $\mathrm{RuO}_{2}$ and $\mathrm{RuO}_{4}$ are the species of main interest, ruthenium hydroxides or oxyhydroxide species in a gaseous state can also exist. Unfortunately, very few data in literature are available on this subject, insofar as no experimental evidence has been published yet. Only a few authors have mentioned them because they have demonstrated their thermodynamic stabilities in the gaseous phase. Two compounds might exist, $\mathrm{RuO}_{3} \mathrm{OH}$ and $\mathrm{RuOH}$. In our conditions, only $\mathrm{RuO}_{3}(\mathrm{OH})$ could come up because it would be stable when temperatures are low. Its partial 
TABLE III

$\mathrm{RuO}_{4}$ Solubility in Water as a Function of Temperature ${ }^{25}$

\begin{tabular}{|c|c|c|c|c|c|c|c|c|c|c|}
\hline & \multicolumn{10}{|c|}{ Temperature $(\mathrm{K})$} \\
\cline { 2 - 13 } & 273 & 283 & 288 & 293 & 298 & 303 & 313 & 323 & 343 & 348 \\
\hline Solubility $(\mathrm{g} / \ell)$ & 17.12 & 18.53 & 19.63 & 20.33 & 21.62 & 21.13 & 20.81 & 20.88 & 21.41 & 22.49 \\
\hline
\end{tabular}

pressure is supposed to be close to $10^{-7}$ bar at $500 \mathrm{~K}$ according to the FACT thermodynamic code. ${ }^{53}$

In the absence of references, all previous equilibrium constants were calculated with $\mathrm{COACH}$, the database associated with GEMINI 1 (Ref. 36).

The study of previous reactions associated with the few experimental results highlights that $\mathrm{RuO}_{2}$ deposits could be oxidized to a significant extent leading to gaseous ruthenium tetroxide formation with partial pressures that may reach $10^{-7}$ to $10^{-5}$ bar in the containment.

\section{IV.B. Ruthenium Thermal Reactivity in Aqueous Phase}

A severe accident leads to the formation of an aqueous phase in the containment (with a minimum volume of $\sim 200 \mathrm{~m}^{3}$ corresponding to the water volume of the RCS for a French 900-MW(electric) PWR, for example).

Ruthenium behavior in aqueous solution has to be considered for an accurate source-term evaluation. Indeed, the aqueous reactions could either trap ruthenium in solution through stabilization or produce volatile ruthenium tetroxide.

Possible forms in solution are mainly $\mathrm{RuO}_{4}$ transferred from the gaseous phase, $\mathrm{RuO}_{2}$ coming from the soluble aerosol settling, and ruthenate and perruthenate coming from the settling of mixed aerosols. Sump pH may vary from 4 to 10 , according to the availability of the spray system.

\section{IV.B.1. Behavior of Dissolved Tetroxide}

Ruthenium tetroxide is a soluble molecule in water, as reported in Table III. According to the $\mathrm{pH}$ solution, it can be present in $\mathrm{H}_{2} \mathrm{RuO}_{5}$ acid form, known as hyperruthenic, and it is an amphoteric species. Martin ${ }^{54}$ suggested that $\mathrm{RuO}_{4}$ could act as a weak acid and as a weak base, as shown with the following equilibria:

weak acid:

$$
\begin{aligned}
\mathrm{RuO}_{4}+\mathrm{H}_{2} \mathrm{O} \Leftrightarrow \mathrm{H}_{2} \mathrm{RuO}_{5} \\
\mathrm{H}_{2} \mathrm{RuO}_{5}+\mathrm{H}_{2} \mathrm{O} \Leftrightarrow \mathrm{HRuO}_{5}^{-}+\mathrm{H}_{3} \mathrm{O}^{+} \quad \mathrm{pKa}=11.2 \text { at } 298 \mathrm{~K}
\end{aligned}
$$

weak base:

$$
\mathrm{H}_{2} \mathrm{RuO}_{5} \Leftrightarrow \mathrm{HRuO}_{4}^{+}+\mathrm{OH}^{-} \quad \mathrm{pKa}=14.2 \text { at } 298 \mathrm{~K} .
$$

Zoubov and Pourbaix ${ }^{55}$ have specified that tetroxide decomposes rapidly with light, forming a black deposit of
$\mathrm{RuO}_{2}, 2 \mathrm{H}_{2} \mathrm{O}$ hydrated dioxide. Hydrochloric acid reduces $\mathrm{RuO}_{4}$ in tetra- and trivalent complex forms, becoming oxidized into chlorine.

Analyses of $\mathrm{pH}-$ potential scale ${ }^{33}$ and that of redox potential values, indicated in Table IV, show that in the $\mathrm{pH}$ range of interest (4 to 10), tetroxide is not stable at $298 \mathrm{~K}$ in aqueous solutions without oxidizing and complexing agents. Reduction to hydrated ruthenium dioxide or into ruthenium metal occurs. In a sodium hydroxide solution, tetroxide is reduced in perruthenate $(\mathrm{Ru}-\mathrm{VII})$ and ruthenate $(\mathrm{Ru}-\mathrm{VI})$ ions ${ }^{26}$ :

$$
2 \mathrm{RuO}_{4}+2 \mathrm{OH}^{-} \rightarrow 2 \mathrm{RuO}_{4}^{-}+\mathrm{H}_{2} \mathrm{O}+0.5 \mathrm{O}_{2}
$$

and

$$
2 \mathrm{RuO}_{4}^{-}+2 \mathrm{OH}^{-} \rightarrow 2 \mathrm{RuO}_{4}^{2-}+\mathrm{H}_{2} \mathrm{O}+0.5 \mathrm{O}_{2} .
$$

Nowogrocki and Tridot ${ }^{56}$ have studied the Eq. (6) reaction in $\mathrm{RuO}_{4}^{-}$concentration range of $\sim 10^{-2} \mathrm{~mol} / \ell$, and the following kinetic rate law was determined:

$$
\begin{aligned}
\frac{-d\left[\mathrm{RuO}_{4}^{-}\right]}{d t} & =k\left[\mathrm{RuO}_{4}^{-}\right]^{2} \cdot\left[\mathrm{OH}^{-}\right]^{3} \\
\text { with } k & =20 \ell^{4} / \mathrm{mol}^{4} \cdot \mathrm{h}(\text { at room temperature }) .
\end{aligned}
$$

Nikitina et al. ${ }^{57}$ have also studied the kinetics of perruthenate reduction into alkaline solution but in much lower concentration ranges $\left(10^{-4} / 10^{-6} \mathrm{~mol} / \ell\right)$. With constant ionic strength, the kinetic rate law of $\mathrm{RuO}_{4}^{-}$reduction was established:

\section{TABLE IV}

Redox Potential in Acid and Alkaline Medium Calculated with a $10^{-10} \mathrm{~mol} / \ell$ Reference Concentration in Ruthenium ${ }^{33}$

\begin{tabular}{|l|c|c|c|}
\hline $\begin{array}{c}\text { Oxidizing/Reducing } \\
\text { Agent }\end{array}$ & $\begin{array}{c}E^{\circ} \\
(\mathrm{V})\end{array}$ & $\begin{array}{c}E^{\circ}(\mathrm{V})-\mathrm{k} \\
\mathrm{pH}(4)\end{array}$ & $\begin{array}{c}E^{\circ}(\mathrm{V})-\mathrm{k} \\
\mathrm{pH}(10)\end{array}$ \\
\hline $\mathrm{RuO}_{4}(\mathrm{aq}) / \mathrm{RuO}_{4}^{2-}$ & 1.59 & 1.59 & 1.59 \\
$\mathrm{RuO}_{4}(\mathrm{aq}) / \mathrm{RuO}_{4}^{-}$ & 1.00 & 1.00 & 1.00 \\
$\mathrm{RuO}_{4}^{2-} / \mathrm{RuO}_{2}$ & 2.01 & 1.24 & 0.53 \\
$\mathrm{RuO}_{4}^{-} / \mathrm{RuO}_{2}$ & 1.53 & 1.02 & 0.55 \\
$\mathrm{RuO}_{4}(\mathrm{aq}) / \mathrm{RuO}_{2}$ & 1.40 & 1.02 & 0.65 \\
$\mathrm{RuO}_{2} / \mathrm{Ru}^{2+}$ & 1.12 & 0.94 & 0.23 \\
$\mathrm{RuO}_{2} / \mathrm{Ru}$ & 0.79 & 0.55 & 0.19 \\
$\mathrm{O}_{2} / \mathrm{H}_{2} \mathrm{O}$ & 1.23 & 0.99 & 0.64 \\
\hline
\end{tabular}




$$
\frac{-d\left[\mathrm{RuO}_{4}^{-}\right]}{d t}=k_{1}\left[\mathrm{RuO}_{4}^{-}\right]^{2} \cdot\left[\mathrm{OH}^{-}\right]+k_{2}\left[\mathrm{RuO}_{4}^{-}\right]
$$

with $k_{1}=0.41 \pm 0.08 \ell^{2} / \mathrm{mol}^{2} \cdot \mathrm{s}$ and $k_{2}=(1.2 \pm 0.3) \times$ $10^{-4} \mathrm{~s}^{-1}$ at $293 \mathrm{~K}$.

These two kinetic rate laws provide very significant differences in the perruthenate disappearance rate.

As shown on the $\mathrm{pH}$-potential scale, at room temperature, orange solutions of ruthenate are stable in a very alkaline medium. If the $\mathrm{pH}$ is sufficiently decreased, below 12 , ruthenate disproportionates into green perruthenate and $\mathrm{RuO}_{2}, 2 \mathrm{H}_{2} \mathrm{O}$, as indicated in Eq. (7):

$$
3 \mathrm{RuO}_{4}^{2-}+4 \mathrm{H}^{+} \rightarrow \mathrm{RuO}_{2}, 2 \mathrm{H}_{2} \mathrm{O}+2 \mathrm{RuO}_{4}^{-} .
$$

This ruthenate disproportionation reaction was checked experimentally by Connick and Hurley, ${ }^{58}$ who worked with quite low ruthenium concentrations, $\sim 10^{-5} \mathrm{~mol} / \ell$. However, they suggested the following general reaction:

$$
3 \mathrm{RuO}_{4}^{2-}+(2+x) \mathrm{H}_{2} \mathrm{O} \rightarrow 2 \mathrm{RuO}_{4}^{-}+\mathrm{RuO}_{2}, x \mathrm{H}_{2} \mathrm{O}+4 \mathrm{OH}^{-} .
$$

The precipitate obtained was analyzed with X-ray diffraction (before and after heating at $413 \mathrm{~K}$ and next at $973 \mathrm{~K}$ ), and the results confirm the $\mathrm{RuO}_{2}, 2 \mathrm{H}_{2} \mathrm{O}$ form.

For $\mathrm{pH}$ lower than 12, perruthenate can now be reduced into hydrated dioxide as follows:

$$
4 \mathrm{RuO}_{4}^{-}+4 \mathrm{H}^{+}+6 \mathrm{H}_{2} \mathrm{O} \rightarrow 4 \mathrm{RuO}_{2}, 2 \mathrm{H}_{2} \mathrm{O}+3 \mathrm{O}_{2} \text {. }
$$

Nevertheless, the degree of hydration of the ruthenium dioxide is still uncertain. Zoubov and Pourbaix ${ }^{55}$ are inclined to favor $\mathrm{RuO}_{2}, 2 \mathrm{H}_{2} \mathrm{O}$ formation, while other authors, like Nowogrocki and Tridot ${ }^{56}$ or Rard, ${ }^{31}$ proposed the generic $\mathrm{Ru}_{2} \mathrm{O}_{5}$, $x \mathrm{H}_{2} \mathrm{O}$ compound formation instead.

Zoubov and Pourbaix ${ }^{55}$ indicated that when $\mathrm{pH}$ is lower than 7.5, ruthenate ion decomposition can lead to the formation of $\mathrm{RuO}_{4}$ or $\mathrm{H}_{2} \mathrm{RuO}_{5}$ (hyperruthenic acid). This statement was also confirmed by Nowogrocki and Tridot, ${ }^{59}$ who performed ruthenate and perruthenate solution acidification tests by making measurements with spectrophotometry, $\mathrm{pH}$-metry, and conductimetry. Ionic equilibria and redox equilibria make it possible to confirm Zoubov's results. They suggest a reactional mechanism that is slightly different from the previous ones, in particular due to the formation of a pentavalent ruthenium hydrated oxide instead of hydrated dioxide, such as

$$
2 \mathrm{RuO}_{4}^{2-}+3 \mathrm{H}^{+} \stackrel{\mathrm{H}_{2} \mathrm{O}}{\longrightarrow} \mathrm{RuO}_{4}^{-}+\mathrm{RuO}_{x}(\mathrm{aq})
$$

and

$$
3 \mathrm{RuO}_{4}^{-}+3 \mathrm{H}^{+} \stackrel{\mathrm{H}_{2} \mathrm{O}}{\longrightarrow} 2 \mathrm{RuO}_{4}+\mathrm{RuO}_{x}(\mathrm{aq})
$$

It can be summarized as

$$
3 \mathrm{RuO}_{4}^{2-}+6 \mathrm{H}^{+} \stackrel{\mathrm{H}_{2} \mathrm{O}}{\longrightarrow} \mathrm{RuO}_{4}+2 \mathrm{RuO}_{x}(\mathrm{aq}) .
$$

Nowogrocki and Tridot ${ }^{56}$ demonstrated the possible formation of volatile ruthenium tetroxide from a $0.5 \mathrm{~N}$ sodium
TABLE V

Stability Domain of Ruthenium Oxides in Aqueous Solution as a Function of $\mathrm{pH}$

\begin{tabular}{|c|c|c|c|}
\hline \multirow{2}{*}{} & \multicolumn{3}{|c|}{$\mathrm{pH}$} \\
\cline { 2 - 4 } & 4 & 7 & 10 \\
\hline Stable species & $\mathrm{RuO}_{2}(\mathrm{c})$ & $\begin{array}{c}\mathrm{RuO}_{2}(\mathrm{c}) \\
\mathrm{RuO}_{4}^{-}\end{array}$ & $\begin{array}{c}\mathrm{RuO}_{4}^{-} \\
\mathrm{RuO}_{4}^{2-}\end{array}$ \\
\hline
\end{tabular}

hydroxide solution containing perruthenate ions in the presence of an oxidizing hypochlorite agent.

This information is important in terms of nuclear safety because these boundary conditions are probable. Ruthenium ionic species $[(+\mathrm{VII})$ and $(+\mathrm{VI})]$ can be present in acid or in alkaline sump; oxidizing agents (due to radiolytic compounds) can also be there. To sum up, the aqueous phase could be a potential source of volatile ruthenium. Table $\mathrm{V}$ recapitulates the stability domain of the main ruthenium compounds as a function of $\mathrm{pH}$ conditions.

\section{IV.B.2. $\mathrm{RuO}_{4}$ Volatility}

In studying $\mathrm{RuO}_{4}$ partition coefficients between the organic phase and the aqueous phase for different acidities, Mar$\operatorname{tin}^{54}$ noticed that ruthenium tetroxide in water and in $\mathrm{CCl}_{4}$ made an ideal mixture (for dissolved $\mathrm{RuO}_{4}$ concentration lower than $0.2 \mathrm{~mol} / \ell ; \mathrm{RuO}_{4}$ vapor pressure in equilibrium with $\mathrm{CCl}_{4}$ solution at $303 \mathrm{~K}$ obeys Henry's law).

Nikol'skii ${ }^{38}$ measured $\mathrm{RuO}_{4}$ saturation vapor pressure between 1 and $364 \mathrm{~K}$. Two empirical equations were recommended to calculate $\mathrm{P}_{\mathrm{SatRuO} 4}$ as a function of temperature (lower or higher than $298 \mathrm{~K}$ corresponding to the tetroxide melting point). Sublimation, vaporization, and fusion enthalpies were also calculated, as well as theoretical melting (298 K) and boiling points $(364 \mathrm{~K})$ :

$$
\text { 1. For } 273 \mathrm{~K}<T<298 \mathrm{~K} \text { : }
$$

$$
\log P=\frac{2880.3}{T}+10.673 \quad(T \text { in } \mathrm{K} \text { and } P \text { in } \mathrm{mm} \mathrm{Hg})
$$

The uncertainty associated with $P$ is $\sim 5 \%$.

$$
\text { 2. For } 298 \mathrm{~K}<T<364 \mathrm{~K} \text { : }
$$

$$
\log P=\frac{-2847.9}{T}+1.74 \log T-0.008406 T+8.737
$$

( $T$ in $\mathrm{K}$ and $P$ in $\mathrm{mm} \mathrm{Hg}$ ).

The uncertainty associated with $P$ is $\sim 2 \%$.

In a comparison between Nikol'skii's values and those of the $\mathrm{COACH}$ thermodynamic database, ${ }^{36} 300$ and $360 \mathrm{~K}$, respectively, are obtained as well as $1.5 \times 10^{3}$ and $2.5 \times 10^{4} \mathrm{~Pa}$ with Nikol'skii relationships and $4.9 \times 10^{2}$ and $8.8 \times 10^{3}$ with the $\mathrm{COACH}$ database. Uncertainties concerning vapor pressure are quite significant. 


\section{IV.B.3. Soluble Ruthenium Dioxide}

Ruthenium dioxide in its hydrated form, $\mathrm{RuO}_{2}, x \mathrm{H}_{2} \mathrm{O}$ with $2<x<3$, may be soluble in the aqueous phase even if solubility turns out to be difficult, especially in a noncomplexing acid medium. ${ }^{33}$

Solubility is due to the formation of the following specific compounds (monomer or polymer):

$$
\begin{aligned}
& \mathrm{RuO}_{2}, 2 \mathrm{H}_{2} \mathrm{O}(\mathrm{c}) \rightarrow \mathrm{Ru}(\mathrm{OH})_{2}^{2+}(\mathrm{aq})+2 \mathrm{OH}^{-} \\
& K_{S}=\left[\mathrm{Ru}(\mathrm{OH})_{2}^{2+}(\mathrm{aq})\right]\left[\mathrm{OH}^{-}\right]^{2}=8.5 \times 10^{-28}
\end{aligned}
$$

and

$$
\begin{gathered}
4 \mathrm{Ru}(\mathrm{OH})_{2}^{2+}+4 \mathrm{H}_{2} \mathrm{O} \rightarrow \mathrm{Ru}_{4}(\mathrm{OH})_{12}^{4+}(\mathrm{aq})+4 \mathrm{H}^{+} \\
K_{S}=7 \times 10^{-46} .
\end{gathered}
$$

There is a slow polymerization of the Ru(IV) monomer, which makes thermodynamically stable tetramer. ${ }^{60,61}$ This species was observed experimentally by Bremard et al. ${ }^{62}$; they also showed that this tetramer can precipitate into an hydroxide according to Eq. (15):

$$
\mathrm{Ru}_{4}(\mathrm{OH})_{12}^{4+}+4 \mathrm{OH}^{-} \rightarrow 4 \mathrm{Ru}(\mathrm{OH})_{4} .
$$

Equation (15) is purely a formality for ion precipitate because it is probably hydrated.

Finally, even if according to the $\mathrm{pH}$-potential scale, $\mathrm{RuO}_{2}, 2 \mathrm{H}_{2} \mathrm{O}$ is insoluble in noncomplexing acid solutions, it can be dissolved partially in mono- or polynuclear forms. It could even appear in a hexavalent state in ruthenate form in the presence of oxygenated alkaline solutions. ${ }^{55}$

\section{IV.B.4. Ruthenium Hydroxides}

$\mathrm{Ru}(\mathrm{OH})_{3}$ hydroxide is stable in aqueous phase whatever the $\mathrm{pH}$ and for a certain range of potential. Otherwise, it is likely to be oxidized into hydrated dioxide $\mathrm{RuO}_{2}, 2 \mathrm{H}_{2} \mathrm{O}$ or $\mathrm{Ru}(\mathrm{OH})_{4}$ even into $\mathrm{RuO}_{4}$; it can also be easily reduced into elementary ruthenium. ${ }^{55}$

\section{IV.B.5. Soluble Ruthenium Aerosols}

When soluble ruthenium aerosols are dissolved, they liberate either ruthenate or perruthenate anions. As a consequence, the chemistry involved is the same as already described for these compounds.

\section{IV.C. Ruthenium Reactivity Under Radiolysis in Aqueous Phase}

The presence of radionuclides in sump in severe-accident conditions will produce a large dose rate (up to $10 \mathrm{kGy} / \mathrm{h}$ ) in this phase and will then lead to aqueous solution radiolysis phenomena. As the main compound in this phase is water, we can easily go back to a water radiolysis issue. Sodium hydroxide introduced via the containment spray system does not question this hypothesis nor the initial presence of boric acid $\left(\mathrm{H}_{3} \mathrm{BO}_{3}\right)$ in the primary system. Water radiolysis produces molecular, ionic, and radical species, which may be either oxidizing or reducing agents. Redox reactions involving ruthenium dissolved species into solution may take place.
Ruthenium can react with radiolytic compounds. The most numerous free radicals are $\mathrm{e}^{-}$(aq) and $\mathrm{OH}^{\bullet} ; \mathrm{H}^{\bullet}$ is present to a lesser extent. ${ }^{63}$

Hydrated electron is a powerful reducing agent, while $\mathrm{OH}^{*}$ is a strong oxidizing agent. Rate constants for radical reactions are often high, $\sim 10^{9}$ to $10^{10} \mathrm{\ell} / \mathrm{mol} \cdot \mathrm{s}$, close to the diffusion limit.

The analyses of redox potentials of $\mathrm{O}_{2} / \mathrm{O}_{2}^{\cdot-}(-0.33 \mathrm{~V})$ and $\left(\mathrm{O}_{2}+2 \mathrm{H}^{+}\right) / \mathrm{H}_{2} \mathrm{O}_{2}(1 \mathrm{~V})$ show that $\mathrm{O}_{2}^{--}$can be either an oxidizing or reducing agent. It is a weaker oxidizing agent than $\mathrm{OH}^{\bullet}$ but able to reduce metallic ions $\left(\mathrm{HO}_{2}^{--}\right.$, its conjugated acid, is stronger than $\mathrm{O}_{2}^{--}$). In an acid medium when there is no reactant, $\mathrm{O}_{2}^{--}$reacts preferentially with $\mathrm{HO}_{2}^{--}$to produce hydrogen peroxide.

Generally, $\mathrm{H}_{2} \mathrm{O}_{2}$ is not very reactive, but its action should not be omitted; it is both an oxidizing and a reducing agent. Indeed, concerning iodine, for example, $\mathrm{H}_{2} \mathrm{O}_{2}$ is able to reduce $\mathrm{I}_{2}$ into $\mathrm{I}^{-}$. Finally, the hydrogen radical $\mathrm{H}^{*}$, which corresponds to conjugated acid of aqueous electron, is also a strong reducing agent.

For the ruthenium safety issue, our interest is limited to the potential role of an oxidizing agent in ruthenium behavior. The redox potential reported in Table VI (Refs. 64 and 65) shows us that the presence of hydroxyl radical $\mathrm{OH}^{*}$ could stabilize $\mathrm{RuO}_{4}(\mathrm{aq})$ due to the very high redox potential of the $\mathrm{OH}^{*} / \mathrm{H}_{2} \mathrm{O}$ coupling, which is also true for the $\mathrm{H}_{2} \mathrm{O}_{2} / \mathrm{H}_{2} \mathrm{O}$ coupling.

So in severe-accident conditions, ruthenium tetroxide could be stable in the sump. Table VII is an update of Table V, taking into account the radiolytic conditions as well as the thermal conditions.

Haïssinsky and Dran ${ }^{66}$ have performed ruthenate ions radiolysis experiments in sodium hydroxide aqueous solution. The radioactive source was ${ }^{60} \mathrm{Co}$ with an activity of $1700 \mathrm{Ci}$ (maximum dose rate, $4.8 \mathrm{kGy} / \mathrm{h}$ ). Sodium ruthenate was reduced into Ru-IV hydroxide precipitate. Nevertheless, perruthenate ions, $\mathrm{RuO}_{4}^{-}$, are supposed to be formed transitorily due to the following oxidation reaction:

$$
\mathrm{RuO}_{4}^{2-}+\mathrm{O}^{\bullet-}+\mathrm{H}_{2} \mathrm{O} \rightarrow \mathrm{RuO}_{4}^{-}+2 \mathrm{OH}^{-} .
$$

Ruthenate reduction yield falls when its concentration rises, which is directly attributed to the reaction with radical-ions $\mathrm{O}^{\bullet-}$. Ruthenate disappearance and $\mathrm{Ru}(\mathrm{IV})$ hydroxide formation increase in aerated solution and at low concentration in

TABLE VI

Redox Potential as a Function of $\mathrm{pH}$, Calculated with a Reference Concentration of $10^{-10} \mathrm{~mol} / \ell$ in Ruthenium ${ }^{33}$

\begin{tabular}{|l|c|c|c|}
\hline $\begin{array}{c}\text { Oxidizing/Reducing } \\
\text { Agent }\end{array}$ & $\begin{array}{c}E^{\circ} \\
(\mathrm{V})\end{array}$ & $\begin{array}{c}E^{\circ}(\mathrm{V})-\mathrm{k} \\
\mathrm{pH}(4)\end{array}$ & $\begin{array}{c}E^{\circ}(\mathrm{V})-\mathrm{k} \\
\mathrm{pH}(10)\end{array}$ \\
\hline $\mathrm{RuO}_{4}(\mathrm{aq}) / \mathrm{RuO}_{4}^{2-}$ & 1.59 & 1.59 & 1.59 \\
$\mathrm{RuO}_{4}(\mathrm{aq}) / \mathrm{RuO}_{4}^{-}$ & 1.00 & 1.00 & 1.00 \\
$\mathrm{RuO}_{4}^{2-} / \mathrm{RuO}_{2}$ & 2.01 & 1.24 & 0.53 \\
$\mathrm{RuO}_{4}^{-} / \mathrm{RuO}_{2}$ & 1.53 & 1.02 & 0.55 \\
$\mathrm{RuO}_{4}(\mathrm{aq}) / \mathrm{RuO}_{2}$ & 1.40 & 1.02 & 0.65 \\
$\mathrm{O}_{2} / \mathrm{H}_{2} \mathrm{O}$ & 1.23 & 0.99 & 0.64 \\
$\mathrm{OH}^{\circ} / \mathrm{H}_{2} \mathrm{O}$ & 2.74 & 2.50 & 2.15 \\
$\mathrm{H}_{2} \mathrm{O}_{2} / \mathrm{H}_{2} \mathrm{O}$ & 1.78 & 1.54 & 1.18 \\
\hline
\end{tabular}


TABLE VII

Stability Range of Ruthenium Oxides as a Function of $\mathrm{pH}$ Containing Oxidizing Agents Formed by Water Radiolysis

\begin{tabular}{|c|c|c|c|}
\hline \multirow{2}{*}{} & \multicolumn{3}{|c|}{$\mathrm{pH}$} \\
\cline { 2 - 4 } & 4 & \multicolumn{1}{|c|}{7} & 10 \\
\hline Stable species & $\begin{array}{l}\mathrm{RuO}_{2}(\mathrm{c}) \\
\mathrm{RuO}_{4}\end{array}$ & $\begin{array}{l}\mathrm{RuO}_{2}(\mathrm{c}) \\
\mathrm{RuO}_{4}^{2-} / \mathrm{RuO}_{4}^{-} \\
\mathrm{RuO}_{4}\end{array}$ & $\begin{array}{c}\mathrm{RuO}_{4}^{2-} \\
\mathrm{RuO}_{4}^{-}\end{array}$ \\
\hline
\end{tabular}

$\mathrm{Ru}(\mathrm{VI})\left(\sim 10^{-4} M\right)$, but the reduction is not complete even for long irradiations (100 h, corresponding to $480 \mathrm{kGy}$ ).

No specific study of reactions between ruthenium compounds and hydrogen peroxide $\left(\mathrm{H}_{2} \mathrm{O}_{2}\right)$ is available in literature.

\section{INTERACTIONS BETWEEN RUTHENIUM OXIDES AND CONTAINMENT SURFACES}

In a French 900-MW(electric) PWR, the internal wall of the reactor containment building is covered with a 6-mm-thick metal skin made of steel, ${ }^{67}$ which ensures leaktightness. This metallic skin is painted to improve leaktightness and protect against corrosion but also for easier decontamination in case of incidents or accidents. The paint that is most often used in the containment is a water-based polyamide epoxy type. Its chemical structure was established in Aujollet's doctoral thesis. ${ }^{68}$ In a 1300- to 1450-MW(electric) PWR, there is no metallic skin, but the concrete wall is also painted in the same way.

Inside the containment, many other elements are made of steel but not painted, e.g., the steam generators and all the hoopings that maintain the heat insulator. Most of these surfaces are made of Types $316 \mathrm{~L}$ and $304 \mathrm{~L}$ stainless steel. ${ }^{23}$

\section{V.A. Reactivity of $\mathrm{RuO}_{4}$ with Surfaces in the Gaseous Phase}

No experimental study of the interaction between gaseous ruthenium tetroxide and paints (epoxy) has been carried out yet. However, it is well known that $\mathrm{RuO}_{4}(\mathrm{~g})$ is very reactive with organic compounds..$^{25-27}$ Tetroxide is used in organic chemistry as an oxidizing agent. Table VIII lists the various organic

TABLE VIII

Organic Compounds Able to Be Oxidized by $\mathrm{RuO}_{4}$

\begin{tabular}{|l|l|}
\hline \multicolumn{1}{|c|}{ Substrates } & \multicolumn{1}{|c|}{ Oxidation Products } \\
\hline Primary alcohols & Aldehydes, carboxylic acids \\
Secondary alcohols & Ketones \\
Aldehydes & Carboxylic acids \\
Alkenes & Aldehydes, carboxylic acids \\
Alkynes & $\alpha$-diketones, carboxylic acids \\
Amides & Imides \\
Ethers & Esters \\
Sulphides & Sulphones \\
\hline
\end{tabular}

compounds that can be oxidized by $\mathrm{RuO}_{4}$. A strong reactivity of tetroxide vapors with the painted surfaces of the containment can be expected.

On the other hand, ruthenium tetroxide affinity for iron oxides has already been studied. ${ }^{52,69}$ Besides, ruthenium was also found on structure material particles (iron and others) after the Chernobyl accident. Kashparov et al. ${ }^{70}$ think that the origin of these particles is linked to the following process: First, ruthenium seems to have been oxidized on the fuel particle surface; second, $\mathrm{RuO}_{4}$ seems to have been vaporized, and these vapors seem to have condensed onto aerosol particles formed by structural materials.

Maas and Longo ${ }^{52}$ mentioned that ruthenium trapping by iron oxides is very efficient, at $\sim 99.9 \%$. The following deposition mechanism was proposed: $\mathrm{RuO}_{4}(\mathrm{~g}) \rightarrow \mathrm{RuO}_{2}(\mathrm{~s})+\mathrm{O}_{2}(\mathrm{~g})$ [Eq. (1)].

The large specific surface of iron oxides and the variability of iron oxidation states are supposed to promote the reduction of $\mathrm{RuO}_{4}$ onto the surface. Even if $\mathrm{RuO}_{2}$ is often considered as fixed irreversibly by iron oxides, thereby avoiding any later revolatilization, the deposition mechanism is not really understood. No existence of mixed ruthenium/iron oxides has yet been mentioned.

Holdoway ${ }^{69}$ performed various tests in order to study ruthenium volatilization and $\mathrm{RuO}_{2}$ deposition phenomena. One of them consisted of heating ruthenium dioxide that had been previously activated $\left[{ }^{103} \mathrm{RuO}_{2}(\mathrm{~s})\right]$ up to $1323 \mathrm{~K}$ in an $\mathrm{O}_{2}$ stream and then following the vaporized ruthenium dioxide progressively deposited along the stainless steel thermal-gradient tube located downstream of the furnace.

The measured deposits are distributed as shown in Table IX. The results obtained clearly indicate the existence of a volatile ruthenium compound, even at low temperature, contrary to thermodynamic predictions. The most probable candidate is ruthenium tetroxide.

Deposition reactions considered by Holdoway are the following:

$$
\mathrm{RuO}_{3}(\mathrm{~g}) \leftrightarrow \mathrm{RuO}_{2}(\mathrm{~s})+\frac{1}{2} \mathrm{O}_{2}
$$

and

$$
\mathrm{RuO}_{4}(\mathrm{~g}) \leftrightarrow \mathrm{RuO}_{2}(\mathrm{~s})+\mathrm{O}_{2}
$$

TABLE IX

Test Results on ${ }^{103} \mathrm{RuO}_{2}$ Deposits on Stainless Steel Surfaces ${ }^{69}$

\begin{tabular}{|c|c|c|}
\hline Sample & $\begin{array}{c}\text { Temperature } \\
(\mathrm{K})\end{array}$ & $\begin{array}{c}{ }^{103} \mathrm{RuO}_{2} \text { Deposited } \\
(\text { gamma-count/min })\end{array}$ \\
\hline 1 & 323 & 1139 \\
2 & 324 & 1474 \\
3 & 328 & 1625 \\
4 & 332 & 2063 \\
5 & 339 & 2695 \\
6 & 353 & 2936 \\
7 & 277 & 4843 \\
8 & 413 & 16092 \\
9 & 465 & 23068 \\
\hline
\end{tabular}


Apparently, ruthenium deposits on steel are not uniform, because deposits take place primarily on already deposited $\mathrm{RuO}_{2}$ and not on still available surface sites. The presence of $\mathrm{RuO}_{2}$ would then catalyze $\mathrm{RuO}_{4}(\mathrm{~g})$ condensation. Moreover, this self-catalytic reduction phenomenon is also mentioned by various authors. ${ }^{24,35,52}$

Ortins de Bettencourt and Jouan ${ }^{24}$ have observed that the nature of the ruthenium deposits varies as a function of the temperature deposition. At $\sim 773 \mathrm{~K}$, ruthenium is deposited in an irreversible way, but at $423 \mathrm{~K}$, the crystals obtained disappear completely when the tube is rinsed. The latter are assumed to be hydrated $\mathrm{RuO}_{2}$ or $\mathrm{Ru}_{2} \mathrm{O}_{5}$, whose existence has already been mentioned by Debray and Joly. ${ }^{42}$

Eichler et al. ${ }^{29}$ also studied adsorption of ruthenium tetroxide onto stainless steel substrates. During thermochromatography tests carried out between 1500 and $300 \mathrm{~K}$, a large proportion of the ruthenium was volatilized under an oxygen stream, and some of it settled in the column at $\sim 800 \mathrm{~K}$; a weak part, probably in $\mathrm{RuO}_{4}$ form, was able to reach the active charcoal trap set at the outlet at room temperature. When quartz powder was added, ruthenium volatility was strongly reduced, and the fraction that reached the charcoal trap was drastically reduced, near zero. Furthermore, a second deposit area, at $\sim 400 \mathrm{~K}$, occurred. The authors interpreted the deposit phenomena with the same reactions as Holdoway [Eqs. (17) and (1)]. The $\mathrm{RuO}_{2}(\mathrm{~s})$ is then in equilibrium either with $\mathrm{RuO}_{3}$ or with $\mathrm{RuO}_{4}$, according to temperature and oxygen partial pressure, as Schäfer et al. ${ }^{30}$ and Bell and Tagami ${ }^{21}$ have already assumed. Finally, Eichler et al. ${ }^{29}$ attributed the low-temperature deposit area at $\sim 400 \mathrm{~K}$ to the formation of $\mathrm{RuO}_{3}(\mathrm{~s})$ in nonequilibrium conditions, even if its existence has not been established. The $\mathrm{RuO}_{3}(\mathrm{~g})$ would no longer be in equilibrium with $\mathrm{RuO}_{2}(\mathrm{~s})$, as expected at high temperatures, but gaseous ruthenium trioxide would condense directly.

Another possible adsorption reaction at quite a low temperature can be $\mathrm{RuO}_{4}(\mathrm{~g}) \rightarrow \mathrm{RuO}_{3}(\mathrm{ads})+\frac{1}{2} \mathrm{O}_{2}$, whose enthalpy of dissociation reaction has been calculated as $-19.3 \pm 11$ $\mathrm{kJ} / \mathrm{mol}$.

The existence of ruthenium trioxide in solid form was also mentioned by Kim and Winograd, ${ }^{71}$ who provide its X-ray photoelectron spectroscopy (XPS) spectrum with binding energy values for $\mathrm{Ru} 3 \mathrm{~d} 5 / 2$ and $\mathrm{O} 1 \mathrm{~s}$. They found a surface layer corresponding to $\mathrm{RuO}_{3}$ on anhydrous $\mathrm{RuO}_{2}(\mathrm{~s})$.

As mentioned previously, Zimmerman et al. ${ }^{35}$ focused their studies on $\mathrm{RuO}_{4}$ photochemical decomposition and the resulting products formed. A thin brown layer of $\mathrm{RuO}_{3}(\mathrm{~s})$ for irradiating photons with a 438.5-nm wavelength was observed. According to the authors, the only energetically possible elementary process would be

$$
2 \mathrm{RuO}_{4}(\mathrm{~g}) \rightarrow 2 \mathrm{RuO}_{3}+\mathrm{O}_{2}(\mathrm{~g})
$$

in which $\mathrm{RuO}_{3}$ could be either gaseous $\left(\Delta G_{298}^{\circ}=+197 \mathrm{~kJ} / \mathrm{mol}\right.$ and $\Delta H_{298}^{\circ}=+264 \mathrm{~kJ} / \mathrm{mol}$ ) or solid.

Sakurai et al. ${ }^{72}$ studied $\mathrm{RuO}_{4}(\mathrm{~g})$ interactions with various surfaces, including stainless steels, at room temperature and low pressure. Contrary to the already quoted hypothesis concerning $\mathrm{RuO}_{4}$ decomposition into $\left(\mathrm{RuO}_{2}+\mathrm{O}_{2}\right)$, they were not able to obtain any experimental evidence about dioxide formation, even if the black color of the deposit is consistent with $\mathrm{RuO}_{2}$. First, no oxygen release was experimentally measured. Second, the spectrum from X-ray diffraction did not corre- spond to that of $\mathrm{RuO}_{2}$ and was different from the wellcharacterized spectra of the oxides of the different metals concerned. Third, they even observed ruthenium deposits on gold, a priori well known to be nonoxidable. These facts meant they could refute the assumption of metal oxidation by ruthenium tetroxide, reduced to $\mathrm{RuO}_{2}$, which led to formation of metal oxides. To support this assumption, no presence of ruthenium mixed oxides with atoms of the various substratum involved was detected by X-ray diffraction (XRD) and XPS analyses. No atom of the metal substratum on the deposit surface was also observed, not even in the subsurface down to a depth of $\sim 20 \AA$. Moreover, temperatures of $\sim 1273 \mathrm{~K}$ are generally necessary to form mixed oxides, ${ }^{73}$ but these tests were carried out at room temperature.

Hydrolysis of this deposit turned out to be efficient and led to hydrogen peroxide release, measured with spectrophotometric and iodometric methods. Some of the hydrolyzed compounds were able to cover the initial ruthenium black deposit and protect it from any later hydrolysis. The oxidation state of the ruthenium deposit was determined to +IV by performing XPS and infrared analysis. According to all these elements, it was concluded that the deposit was not $\mathrm{RuO}_{2}$ but a ruthenium tetroxide form modified being in contact with the metal. In fact, a $\mathrm{RuO}_{4}$ molecule is supposed to be linked to another one via peroxide $\mathrm{Ru}-\mathrm{O}-\mathrm{O}-\mathrm{Ru}$ bonds. In that case, the black deposit observed would consist of $\left(\mathrm{RuO}_{4}\right)_{n}$ polymerized with peroxide bonds.

The hydrolysis reaction may correspond to ruthenium hydroxide formation:

$$
2 \mathrm{RuO}_{4 \text { (deposit) }}+8 \mathrm{H}_{2} \mathrm{O} \rightarrow 2 \mathrm{Ru}(\mathrm{OH})_{3}+5 \mathrm{H}_{2} \mathrm{O}_{2} \text {. }
$$

Using XRD spectral analysis, Cains and Barnes ${ }^{74}$ have also characterized ruthenium deposits formed from $\mathrm{RuO}_{4}(\mathrm{~g})$, at temperatures of $\sim 423 \mathrm{~K}$ and above. Ruthenium dioxide in crystal form was determined without any bonds with ferrous metal. The XPS analysis of Ru 3p and 3d levels confirmed it.

Supposing ruthenium tetroxide can be adsorbed easily on iron substrates, the information published in literature is not consistent concerning the adsorption mechanism involved and the deposited products resulting from the ruthenium-iron oxide interaction. If a pseudoconsensus about the ruthenium dioxide presence in the deposits exist, others species might be expected.

\section{V.B. Reactivity of Dissolved Species with Immersed Surfaces}

Immersed surfaces in sump contain substrates that are potentially reactive toward ruthenium species dissolved in this aqueous phase. Nevertheless, the total surface is quite small compared with total surface in the atmosphere. Most of the immersed steel or concrete surfaces are painted, while a small section of steel surface is not painted. No data were found in the literature on paint/dissolved ruthenium interactions, but reactivity to stainless steel has already been broached.

Carlson ${ }^{75}$ studied the deposit of dissolved ruthenium onto stainless steel-etched plates for $6 \mathrm{~h}$ in buffer solutions at $\mathrm{pH} 4$, 7 , and 9 at $333 \mathrm{~K}$. The $\mathrm{pH}$ increases ruthenium adsorption on stainless steel. Whatever the buffer employed, the fraction deposited after $24 \mathrm{~h}$ (or $168 \mathrm{~h}$ ) is always low, the maximum is reached at $\mathrm{pH} 9$, with $\sim 10 \%$, while it is only 1 and $0.5 \%$ at $\mathrm{pH} 7$ and 4, respectively. At pH 9, equilibrium is not reached after $24 \mathrm{~h}$; the kinetics of adsorption is slow. The temperature 
effect is significant; indeed, the deposited ruthenium fraction gradually rises with temperature over the 6-h test. Ruthenium deposit did not appear homogeneous on sample plates; it depends strongly on the nature of the metal surface and on the presence, or not, of available adsorption sites. Finally, tests for redissolution were not conclusive, the desorbed fraction is very weak, and ruthenium is probably chemisorbed.

Belloni et al. ${ }^{76}$ carried out experiments on the adsorption of ruthenium on different surfaces, such as platinum, glass, silver, etc. Unlike some other fission products, ruthenium adsorption does not follow a Langmuir isotherm, but the kinetics obeys Henry's law (linear isotherm). Moreover, ruthenium adsorption increases with temperature ${ }^{75,76}$ and is barely reversible.

Finally, we point to the existence of an American patent ${ }^{77}$ that reveals inhibition of stainless steel corrosion when there is ruthenium in acid solution in contact with steel surfaces. This may be due to surface covering with $\mathrm{RuO}_{2}$, which would then have a covering property and such adsorption on steel would prevent any corrosion phenomenon. This mechanism is very probable if a parallel is drawn between ruthenium and technetium. Indeed, chemical properties of $\mathrm{RuO}_{2}$ are close to those of $\mathrm{TcO}_{2}$, but pertechnetate ions, $\mathrm{TcO}_{4}^{-}$, even in very low concentration, are well known ${ }^{33}$ to have electrolytic iron and mild steel corrosion inhibitive properties due to the formation of an insoluble $\mathrm{TcO}_{2}$ film on their surface.

To sum up, ruthenium species are expected to be reactive on immersed surfaces with steel or with paint, and the trapping seems to be almost irreversible.

\section{CONCLUSION}

Basically, the ruthenium chemistry is very complex and all the more so in severe-accident conditions where radiolytic phenomena are involved.

Ruthenium tetroxide is the most volatile ruthenium oxide in the conditions prevailing in the containment, with potentially large consequences on the source term, so understanding its behavior is important, because for accidents involving highly oxidizing conditions such as air ingress, its presence in the containment reactor is suspected.

From a thermodynamic point of view, ruthenium tetroxide is not stable at $\sim 373 \mathrm{~K}$, but kinetic effect seems to occur and could allow its existence for a while, promoted by the presence of air radiolysis products in the atmosphere resulting in rather oxidizing conditions. Experimental data tend to prove that $\mathrm{RuO}_{4}$ remains stable at room temperature for a certain period of time.

Even if there are some discrepancies in literature concerning the adsorption mechanisms involved and the deposited products resulting from the ruthenium-stainless steel surfaces interaction, it is obvious that tetroxide is also very reactive to steel and paints. This is true for immersed surfaces as well.

In the sump, the oxidizing agents formed by water radiolysis could oxidize ruthenate and perruthenate ions in ruthenium tetroxide.

Concerning ruthenium dioxide, which is the main compound of ruthenium expected to reach the containment in aerosol form, it is generally not soluble and it will be distributed in the sump after settling or will be deposited onto walls in the atmosphere. Nevertheless, considering redox potential, it can be expected that a fraction of the ruthenium dioxide deposits could be oxidized by ozone, which is a product of air radiolysis. Unfortunately, no data were found in literature concerning this potential reaction, which could greatly impact the ruthenium source term.

For all the aforementioned reasons, it is of primary importance to obtain experimental data on ruthenium behavior in severe-accident containment conditions, and more precisely on ruthenium tetroxide stability in the gaseous phase, and on possible formation of this oxide from ruthenium deposits or from ruthenate and perruthenate anions.

In the near future, experiments will be carried out to explore this field to better quantify the ruthenium source term and obtain data on kinetics concerning all these potentially relevant reactions.

\section{ACKNOWLEDGMENTS}

The authors thank M. P. Kissane and P. Taylor for the information provided about ruthenium release and transport. Special thanks go to Bernard Clément and Patrice Giordano who agreed to review this paper.

\section{REFERENCES}

1. D. POWERS, L. N. KMETHYK, and R. C. SCHMIDT, "A Review of the Technical Issues of Air Ingression During Severe Reactor Accidents," NUREG/CR-6218, U.S. Nuclear Regulatory Commission (1994).

2. P. GIORDANO and C. SÉROPIAN, "The Air Ingress Issues in PWRs," Proc. 5th Technical Seminar on the Phebus FP Programme, Aix-en-Provence, France, June 24-26, 2003.

3. L. SOFFER, S. B. BURSON, C. M. FERRELL, R. Y. LEE, and J. N. RIDGELY, "Accident Source Terms for Light-Water Nuclear Power Plants," NUREG 1465, U.S. Nuclear Regulatory Commission (1995).

4. J. M. EVRARD, C. MARCHAND, E. RAIMOND, and M. DURIN, "Use of PHEBUS FP Experimental Results for Source Term Assessment and Level 2 PSA," Proc. 5th Technical Seminar on the Phebus FP Programme, Aix-en-Provence, France, June 24-26, 2003.

5. M. E. FRAZIER, T. K. ANDREWS, B. B. THOMPSON, and M. A. WINCEK, "Evaluation of Toxic Effects of Heavy Metals and Chelating Agents in VERO Cells," Pacific Northwest Laboratory (1977).

6. B. SZUBINSKA and J. H. LUFT, "Ruthenium Red and Violet. III-Fine Structure of the Plasma Membrane and Extraneous Coats in Amoebae (A Proteus and Chaos Chaos)," Anat. Rec., 171, 417 (1971).

7. R. MASSE, "Le ruthénium, les métaux activés," Toxiques $\mathrm{Nu}$ cléaires, p. 112, MASSON, Ed. (1982).

8. "Décret relatif à la protection des travailleurs contre les dangers des rayonnements ionisants $-\mathrm{n}^{\circ} 2003-296$, paru au JO n ${ }^{\circ} 78 \mathrm{du} 02 /$ 04/03" (2003).

9. R. PÖLLÄNEN, "Highly Radioactive Ruthenium Particles Released from Chernobyl Accident: Particles Characteristics and Radiological Hazard," Radiat. Prot. Dosim., 71, 23 (1997). 
10. J. LIBMANN, Eléments de sûreté nucléaire-Les éditions de physique, Institute for Protection and Nuclear Safety (1996).

11. C. E. L. HUNT, D. S. COX, and F. C. IGLESIAS, "Fission Product Release During Accidents-An Accident Management Perspective," Nucl. Eng. Des., 148, 205 (1994).

12. R. D. BARRAND, "Release of Fission Products from CANDU Fuel in Air, Steam and Argon Atmospheres at $1500-1900^{\circ} \mathrm{C}$ : The HCE3 Experiment," Proc. 6th Int. CANDU Fuel Conf., Canadian Nuclear Society (1999).

13. Z. HÓZER, L. MATUS, and P. WINDBERG, "CODEX and RUSET Air Oxidation Experiments," Proc. 5th Technical Seminar Phebus FP Programme, Aix-en-Provence, France, June 24-26, 2003.

14. U. BACKMAN, M. LIPPONEN, A. AUVINEN, U. TAPPER, R. ZILLIACUS, and J. K. JOKINIEMI, "On the Transport and Speciation of Ruthenium in High Temperature Oxidising Conditions," Radiochim. Acta, 93, 297 (2005).

15. A. M. BEARD, "Late Phase Source Term Phenomena," SAMLPP-D32, European Union (2003).

16. M. P. KISSANE, "Air Ingress with Particular Regard to the Release and Transport of Ruthenium: A Review of Information from Experiments," IRSN/DPAM 2005-170, Institut de Radioprotection et de Sûreté Nucléaire (2005).

17. H. M. APSIMON and N. MAHADEVA, "The Behaviour of Ruthenium Isotopes Released from Chernobyl," presented at ScopeRadpath Workshop, United Kingdom, 1989.

18. H. ALBRECHT, "Radioactivity Emission from the Chernobyl Accident in Comparison with the Results of Sascha Program," Radiochim. Acta, 41, 141 (1987).

19. R. BRODA, J. W. MIETELSKI, and J. SIENIAWSKI, " ${ }^{125} \mathrm{Sb}$ and ${ }^{60} \mathrm{Co}$ in Ruthenium Hot Particles from Chernobyl Fallout," J. Radioanal. Nucl. Chem., 166, 3, 173 (1992).

20. C. MARCHAND, "Relâchement et transport du ruthénium lors d'une entrée d'air dans la cuve d'un réacteur," Personal Communication (1992).

21. W. E. BELL and M. TAGAMI, "High-Temperature Chemistry of the Ruthenium-Oxygen System,” J. Phys. Chem., 67, 2432 (1963).

22. C. COURTOIS, "Oxydes du ruthénium et piégeage des composés volatils du ruthénium,” BIB-213, Commissariat à l'Energie Atomique (1974).

23. H. E. McGANNON, The Making, Shaping and Treating of Steel, 9th ed. (1970).

24. A. ORTINS DE BETTENCOURT and A. JOUAN, "Volatilité du ruthénium au cours des opérations de vitrification des produits de fission (2ème partie)," CEA-R-3663 (2), Commissariat à l'Energie Atomique (1969).

25. P. PASCAL, Nouveau traité de chimie minérale -Tome XIX, pp. 21171 (1958).

26. E. A. SEDDON and K. R. SEDDON, The Chemistry of Ruthenium. Monograph 19, Elsevier, New York (1984).

27. W. COTTON, Advanced Inorganic Chemistry, 3rd ed., WileyInterscience, New York (1972).
28. "Iodine Aspects of Severe Accident Management," Proc. Workshop, Helsinki, Finland, May 18-20, 1999, OECD Nuclear Energy Agency (1999).

29. B. EICHLER, F. ZUDE, W. FAN, N. TRAUTMANN, and G. HERRMANN, "Volatilization and Deposition of Ruthenium Oxides," Radiochim. Acta, 56, 133 (1992).

30. H. SCHÄFER, G. SCHNEIDEREIT, and W. GERHARDT, " $\mathrm{RuO}_{2}$ chemischer transport, eigenschaften thermische zerfall," $Z$. Anorg. Allg. Chem., 319, 327 (1963).

31. J. A. RARD, "Chemistry and Thermodynamics of Ruthenium and Some of Its Inorganic Compounds and Aqueous Species," J. Am. Chem. Soc., 85, 1, 1 (1985).

32. J. H. NORMAN, H. G. STALEY, and W. E. BELL, Adv. Chem. Ser., 72, 101 (1968).

33. M. POURBAIX, Atlas d'équilibres électrochimiques, GauthierVillars, Paris, France (1963).

34. F. GARISTO, Thermodynamic Behaviour of Ruthenium at High Temperatures, Whiteshell Nuclear Research Establishment, Pinawa, Manitoba, Canada (1988).

35. G. L. ZIMMERMAN, S. J. RIVIELLO, T. A. GLAUSER, and J. G. KAY, "Photochemical Decomposition of $\mathrm{RuO}_{4}$," J. Am. Chem. Soc., 94, 2399 (1990).

36. Available on the internet at www.cicg.grenet.fr.

37. T. SATO, "Instability of Some Nitrosylruthenium Compounds in Nitric Acid," Radiochim. Acta, 46, 213 (1989).

38. A. B. NIKOL'SKII, "Saturated Vapour Pressure of Ruthenium Tetroxide," Russian J. Inorg. Chem., 8, 5 (1963) (English translation).

39. H. SAINTE CLAIRE DEVILLE and H. DEBRAY, C. R. Acad. Sci., 80, 457 (1875).

40. A. LEUDET, "Comportement du ruthénium à la dissolutionEntraînement dans les effluents gazeux," CEA/DGR-224 (classé confidential), Commissariat à l'Energie Atomique (1981).

41. M. H. ORTNER, IDO 14504 (1961).

42. H. DEBRAY and A. JOLY, C. R. Acad. Sci., 106, 328 (1888).

43. L. WÖHLER, PH. BALZ, and L. METZ, "Die Oxyde des Rutheniums," Z. Anorg. Allg. Chem., 139, 1, 205 (1924).

44. A. C. VIKIS and D. F. TORGERSON, Proc. Specialists' Workshop on Iodine Chemistry in Reactor Safety, AERE-R11974, Atomic Energy Research Establishment (1986).

45. Y. KANDA, T. MOMOSE, and M. TAIRA, "Characterization of Radiolytic Products from Air at a High-Energy Electron-Positron Storage Ring," Radiat. Phys. Chem., 48, 1, 49 (1996).

46. J. K. LINACRE and W. R. MARSH, "Radiation Chemistry of Heterogeneous and Homogeneous Nitrogen and Water Systems," AERE-R 10027, p. 1, Atomic Energy Research Establishment (1981).

47. C. WILLIS and A. W. BOYD, "Excitation in the Radiation Chemistry of Inorganic Gases," Int. J. Radiat. Phys. Chem., 8, 71 (1976). 
48. F. AUBERT, "Destruction par radiolyse gamma de l'iodure de méthyle en faible concentration dans l'air humide," Thesis, Université Aix-Marseille III (2002).

49. H. IGARASHI, K. KATO, and T. TAKAHASHI, "Absorption Behaviour of Ruthenium into Water," Radiochim. Acta, 57, 51 (1992).

50. J. M. FLETCHER, I. L. JENKINS, F. M. LEVER, F. S. MARTIN, A. R. POWELL, and R. TODD, "Nitrato and Nitro Complexes of Nitrosylruthenium," J. Inorg. Nucl. Chem., 1, 378 (1955).

51. F. MOUSSET, "Electro-volatilisation du ruthénium en milieu nitrique,” Thesis, Université Paris-VI (2004).

52. E. T. MAAS and J. M. LONGO, "Confinement of Ruthenium Oxides Volatilized During Nuclear Fuels Reprocessing," Nucl. Technol., 47, 451 (1980).

53. C. W. BALE and A. D. PELTON, Fact-win User Manual, 1999, Ecole polytechnique de Montréal (1999).

54. F. S. MARTIN, "The Distribution of Ruthenium Tetroxide Between Carbon Tetrachloride and Aqueous Alkali, Acid and Neutral Salt Solutions," J. Chem. Soc., 2564 (1954).

55. N. ZOUBOV and M. POURBAIX, "Comportement électrochimique du ruthénium. Diagrammes d'équilibres tension- $\mathrm{pH}$ du système Ru-H $\mathrm{H}_{2} \mathrm{O}$," RT.58, CEBELCOR (1958).

56. G. NOWOGROCKI and G. TRIDOT, "Cinétique de la filiation des ions perruthénates et ruthénates en milieu alcalin. Application analytique," Bull. Soc. Chim. France, 123, 684 (1965).

57. G. P. NIKITINA, YU. E. IVANOV, V. P. EGOROVA, M. F. PUSHLENKOV, and V. G. SHUMKOV, "Reduction Kinetics of Perruthenate in Alkaline Solutions," Translated from Kinetika i Kataliz, 14, 1435 (1973).

58. R. E. CONNICK and C. R. HURLEY, "Chemistry of Ru (VI), -(VII), -(VIII). Reaction, Oxidation Potentials and Spectra," J. Am. Chem. Soc., 74, 5012 (1952).

59. G. NOWOGROCKI and G. TRIDOT, "Etude de l'acidification des solutions de ruthénates et perruthénates," Bull. Soc. Chim. France, 124, 688 (1965)

60. J. A. RARD, "Thermodynamic Data Bases for Multivalent Elements: An Example for Ruthenium," Proc. Int. Conf. Thermodynamics of Aqueous Systems with Industrial Applications, May 10-14, 1987, Warrenton, Virginia.

61. V. M. VDOVENKO, L. N. LAZAREV, and Y. S. KHVOROSTIN, "Investigations of Ru(IV) Solutions in Perchloric and Sulfuric Acids," Translated from Radiokhim., 7, 2, 232 (1965).

62. C. BREMARD, G. NOWOGROCKI, and G. TRIDOT, "Le degré d'oxydation IV du ruthénium. Etude des espèces ioniques et de la précipitation de l'hydroxyde en milieu non complexant," Bull. Soc. Chim. France, 76, 392 (1974).
63. R. FARHATAZIZ, Radiation Chemistry, Principles and Applications, VCH, New York (1987).

64. U. K. KLANING, K. SEHESTED, and J. HOLCMAN, "Standard Gibbs Energy of Formation of the Hydroxyl Radical in Aqueous Solution," J. Phys. Chem., 89, 760 (1985).

65. H. A. SCHWARZ and R. W. DODSON, "Equilibrium between Hydroxyl Radicals and Thallium(II) and the Oxidation Potential of OH(aq)," J. Phys. Chem., 88, 3643 (1984).

66. M. HAÏSSINSKY and J. C. DRAN, "Radiolyse de composés de métaux nobles en solution aqueuse. Réduction radiolytique du ruthénate de sodium," Bull. Soc. Chim. France, 15, 321 (1967).

67. J. L. COSTAZ, “Techniques de l'ingénieur," Confinement - Enceintes (2004).

68. Y. AUJOLLET, "Etudes de intéractions chimiques iode-peinture dans un réacteur nucléaire (réacteur à eau pressurisée) en situation d'accident grave," Thesis, Université Aix-Marseille III (1999).

69. M. J. HOLDOWAY, "The Volatilisation and Deposition of Ruthenium Dioxide in Relation to Fingal Process," AERE-R6418, Atomic Energy Research Establishment (1971).

70. V. A. KASHPAROV, Y. A. IVANOV, S. I. ZVARISH, V. P. PROTSAK, Y. V. KHOMUTININ, A. D. KUREPIN, and E. M. PAZUKIN, "Formation of Hot Particles During the Chernobyl Nuclear Power Plant Accident—Radioactive Waste Management," NT-5 9148 (1995).

71. K. S. KIM and N. WINOGRAD, "X-Ray Photoelectron Spectroscopic Studies,” J. Catalysis, 35, 66 (1974).

72. T. SAKURAI, Y. HINATSU, A. TAKAHASHI, and G. FUJISAWA, "Adsorption of Ruthenium Tetroxide on Metal Surfaces," J. Phys. Chem., 89, 1892 (1985).

73. J. DULAC, "Composés spinelles formés entre l'oxyde de ruthénium $\mathrm{RuO}_{2}$ et les oxydes de certains métaux de transition," Bull. Soc. Fr. Mineral. Cristalllogr., 92, 487 (1969).

74. P. W. CAINS and S. J. BARNES, "Deposition of Volatilized Ruthenium on Stainless Steels," J. Nucl. Mater., 186, 83 (1991).

75. A. B. CARLSON, "Contamination and Decontamination of Low Temperature, Water-Cooled Reactors (Part 1: Dissolved Radionuclides on Stainless and Mild Steels)," TID-4500, Savannah River Laboratory (1962).

76. J. BELLONI, M. HAISSINSKY, and H. N. SALAMA, "On the Adsorption of Some Fission Products on Various Surfaces," J. Phys. Chem., 63, 881 (1959).

77. R. F. MANESS, "Inhibiting Corrosion of Stainless Steel by Ruthenium Containing Nitric Acid Solution,” U.S. Patent 4,111,831 (1978) 